\title{
Photoactive Complexes with Earth-Abundant Metals
}

\author{
Oliver S. Wenger* \\ Department of Chemistry, University of Basel, St. Johanns-Ring 19, 4056 Basel, Switzerland
}

\begin{abstract}
In this invited Perspective recent developments and possible future directions of research on photoactive coordination compounds made from non-precious transition metal elements will be discussed. The focus is on conceptually new, structurally well-characterized complexes with excited-state lifetimes between $10 \mathrm{ps}$ and $1 \mathrm{~ms}$ in fluid solution for possible applications in photosensitizing, light-harvesting, luminescence, and catalysis. The key metal elements considered herein are $\mathrm{Cr}, \mathrm{Mn}, \mathrm{Fe}, \mathrm{Co}, \mathrm{Ni}, \mathrm{Cu}, \mathrm{Zn}, \mathrm{Zr}, \mathrm{Mo}, \mathrm{W}$, and $\mathrm{Ce}$ in various oxidation states equipped with diverse ligands, giving access to long-lived excited states via a range of fundamentally different types of electronic transitions. Research performed in this area over the past five years demonstrated that a much broader spectrum of metal complexes than what was long believed relevant exhibits useful photophysics and photochemistry.
\end{abstract}

\section{INTRODUCTION}

Most molecular compounds dissipate excitation energy very rapidly in non-radiative fashion, and only a small fraction have electronic excited states with lifetimes exceeding a few hundred picoseconds, from which luminescence or photochemical reactions typically can occur. A key prerequisite for such behavior is a sufficiently large energy gap between the electronic ground state and the lowest excited state, but other factors such as what types of molecular distortions are associated with an electronic excitation and what kinds of molecular vibrations are coupled to it play important roles as well. The combination of all relevant factors leads to a very stringent set of criteria that must be fulfilled to obtain compounds with long-lived (photoactive) excited states. ${ }^{1}$

Inorganic photophysics and photochemistry has long focused on six-coordinate metal complexes with low-spin $4^{6} \mathrm{~d}^{6}$ and $5 \mathrm{~d}^{6}$ electron configurations. ${ }^{2}$ The ligand field splitting in $2^{\text {nd }}$ and $3^{\text {rd }}$ row transition metals is inherently larger than for $3 \mathrm{~d}$-metals, shifting $\mathrm{d}$-d excited states to higher energies, and this is advantageous because many of them are potentially non-emissive due to sizeable molecular distortions as a result of the promotion of electrons into antibonding metal-ligand orbitals. Combined with (chelating) $\pi$-acceptor ligands, metal cations such as $\mathrm{Ru}(\mathrm{II})$, $\operatorname{Re}(\mathrm{I})$, Os(II), or $\operatorname{Ir}(\mathrm{III})$ therefore often lead to complexes that have MLCT states lower than d-d excited states. Efficient intersystem crossing enabled by the heavy metals then usually populates emissive ${ }^{3}$ MLCT states exhibiting relatively slow radiative and non-radiative relaxation. This, along with the fact that the redox properties in the ${ }^{3}$ MLCT states are drastically altered with respect to the electronic ground state, makes these complexes so interesting for various applications, for example solar energy conversion or photoredox catalysis. ${ }^{3}$

Another key class of photoactive metal complexes is comprised of four-coordinate $5 \mathrm{~d}^{8}$ complexes made from
$\mathrm{Pt}(\mathrm{II})$ and $\mathrm{Au}(\mathrm{III})$, which also benefit from the strong ligand fields provided by $3^{\text {rd }}$ row transition metals. ${ }^{4}$ Thus, many of the most frequently investigated photoactive complexes are made from precious metals with very low abundance in Earth's crust (Table 1). There has been a long-standing interest in photoactive molecular complexes made from abundant elements with scattered reports on different metals, but $\mathrm{Cu}(\mathrm{I}), \mathrm{Fe}(\mathrm{II})$ and $\mathrm{Cr}$ (III) received considerable attention from early on. The complete lack of possible $\mathrm{d}-\mathrm{d}$ excitations in the $3 \mathrm{~d}^{10}$ configuration makes $\mathrm{Cu}(\mathrm{I})$ very interesting for MLCT emitters, and in the $3 \mathrm{~d}^{3}$ configuration of octahedral $\mathrm{Cr}$ (III) complexes there can be low lying d-d states with spin-flip character leading to favorably small molecular distortions. Classical $\mathrm{Cu}(\mathrm{I}) \alpha-$ diimine complexes have been reviewed extensively and will not be considered here. 5 Likewise, work on photoactive $\mathrm{Cr}$ (III) complexes has been reviewed before and only the latest developments will be included here. ${ }^{2,6}$

Table 1. Abundance of some metal elements in Earth's crust (in mass percent). ${ }^{7}$

\begin{tabular}{|l|l|l|l|l|l|}
\hline $\begin{array}{l}\text { ele- } \\
\text { ment }\end{array}$ & $\begin{array}{l}\text { abun- } \\
\text { dance }\end{array}$ & $\begin{array}{l}\text { ele- } \\
\text { ment }\end{array}$ & $\begin{array}{l}\text { abun- } \\
\text { dance }\end{array}$ & $\begin{array}{l}\text { ele- } \\
\text { ment }\end{array}$ & $\begin{array}{l}\text { abun- } \\
\text { dance }\end{array}$ \\
\hline $\mathrm{Ru}$ & $10^{-6}$ & $\mathrm{Cr}$ & 0.01 & $\mathrm{Zn}$ & 0.007 \\
\hline $\mathrm{Re}$ & $10^{-7}$ & $\mathrm{Mn}$ & 0.091 & $\mathrm{Zr}$ & 0.016 \\
\hline $\mathrm{Os}$ & $5 \cdot 10^{-7}$ & $\mathrm{Fe}$ & $4 \cdot 7$ & $\mathrm{Mo}$ & $1.4 \cdot 10^{-4}$ \\
\hline $\mathrm{Ir}$ & $10^{-7}$ & $\mathrm{Co}$ & $2.4 \cdot 10^{-3}$ & $\mathrm{Ce}$ & 0.006 \\
\hline $\mathrm{Pt}$ & $10^{-6}$ & $\mathrm{Ni}$ & $7.2 \cdot 10^{-3}$ & $\mathrm{~W}$ & $1.5 \cdot 10^{-4}$ \\
\hline $\mathrm{Au}$ & $4 \cdot 10^{-7}$ & $\mathrm{Cu}$ & 0.005 & $\mathrm{U}$ & $1.7 \cdot 10^{-4}$ \\
\hline
\end{tabular}

Over the past five years a range of conceptually novel discoveries regarding photoactive metal complexes have been made and this will be the main focus of this Perspective. Sometimes this progress was driven by physical- 
inorganic chemists aiming to synthesize and explore new photoactive complexes based on careful molecular design, whilst in other instances progress was made in a more serendipitous manner in the course of photoredox studies. During the latter, occasionally new complexes formed as a result of substrate binding, and sometimes it was not fully clear what the photoactive species really is. This Perspective will only consider isolated, structurally well characterized complexes, and the focus is on complexes with excited-state lifetimes in the range of $10 \mathrm{ps}$ to $1 \mathrm{~ms}$ in fluid solution. The article is structured into different metal element sections, considering that sometimes multiple oxidation states of the same metal can lead to complexes with very different types of photoactive excited states.

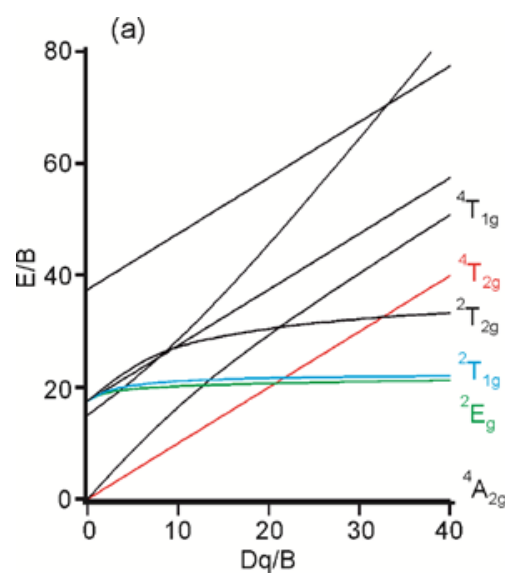

(b)

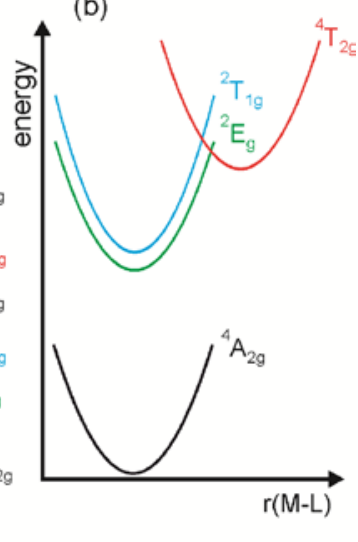

Figure 1. (a) Tanabe-Sugano diagram for the $\mathrm{d}^{3}$ electron configuration in $\mathrm{O}_{\mathrm{h}}$ symmetry and (b) potential energy wells for key electronic states in $\mathrm{Cr}$ (III) spin-flip emitters.

\section{CHROMIUM AND MANGANESE}

Ruby was used to build the first laser, taking advantage of the three-level system arising from the ${ }^{4} \mathrm{~A}_{2 \mathrm{~g}}$ ground state and the ${ }^{4} \mathrm{~T}_{2 \mathrm{~g}}$ and ${ }^{2} \mathrm{E}_{\mathrm{g}}$ excited states (in idealized $\mathrm{O}_{\mathrm{h}}$ point symmetry, Figure 1). Recently, Heinze and coworkers reported on a molecular version of ruby, namely a homoleptic $\mathrm{Cr}(\mathrm{III})$ complex with two tridentate chelate ligands providing a very strong ligand field and nearly ideal bite angles (Figure 2a). ${ }^{8}$ Contrary to most previously investigated emissive $\mathrm{Cr}(\mathrm{III})$ complexes, $\left[\mathrm{Cr}(\mathrm{ddpd})_{2}\right]^{3+}$ has a nearly perfectly octahedral $\mathrm{CrN}_{6}$ primary coordination sphere. This is important because in lower symmetries the relevant energy gaps are reduced, leading to efficient non-radiative quenching. $\left[\mathrm{Cr}(\mathrm{ddpd})_{2}\right]^{3+}$ emits ${ }^{2} \mathrm{E}_{\mathrm{g}} \rightarrow{ }^{4} \mathrm{~A}_{2 \mathrm{~g}}$ (spin-flip) luminescence at $775 \mathrm{~nm}$ with a spectacular lifetime $(\tau)$ of $898 \mu$ s and a quantum yield $(\phi)$ of $11 \%$ in deaerated $\mathrm{H}_{2} \mathrm{O}$ at room temperature (Table 2). For comparison, the $\left[\mathrm{Cr}(\text { tpy })_{2}\right]^{3+}$ complex (Figure $2 \mathrm{~b}$ ) (tpy $=2,2^{\prime}: 6^{\prime}, 2^{\prime \prime}-$ terpyridine) has $\tau<30 \mu$ s and $\phi=0.00089 \%$ under identical conditions. ${ }^{8}$ Ligand deuteration leads to a further improvement of the luminescence properties. 9 In particular, deuteration at the $\mathrm{C}$-atoms in $\alpha$-position to the $\mathrm{N}$-atom has a strong effect, presumably due to the proximity to the metal center. ${ }^{10}$ When replacing the $\mathrm{CH}_{3}$ groups by $\mathrm{D}$ atoms, the resulting complex exhibits very similar luminescence properties as the parent compound, indicating that the effects of $\mathrm{N}$-methylation and $\mathrm{N}$-deuteration are comparable as far as non-radiative relaxation is concerned. ${ }^{11}$ (a)

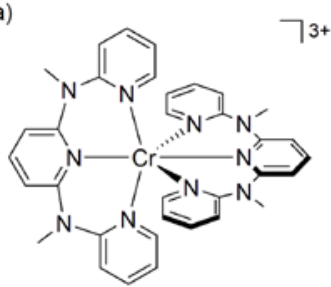

(c)

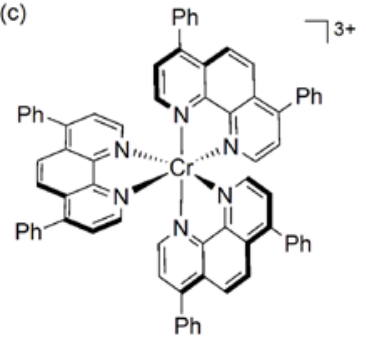

(e)

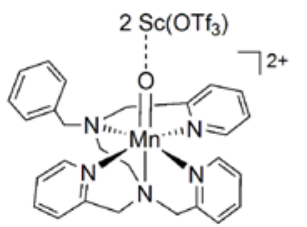

(b) $7^{3+}$

(d)

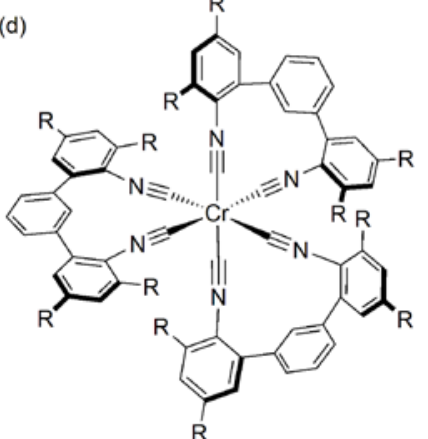

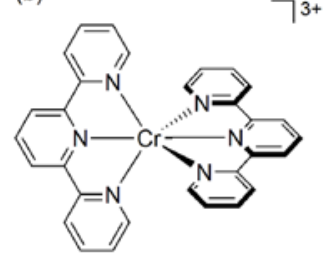

Figure 2. Molecular structures of $\mathrm{Cr}$ complexes: (a) $\left[\mathrm{Cr}(\mathrm{ddpd})_{2}\right]^{3+; 8,12}$ (b) $\left[\mathrm{Cr}(\mathrm{tpy})_{2}\right]^{3^{+}}$; (c) $\left[\mathrm{Cr}\left(\mathrm{ph}_{2} \text { phen }\right)_{3}\right]^{3^{++} ; 1^{3}}$ (d)

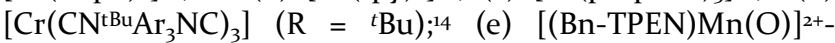
$\left[\mathrm{Sc}(\mathrm{OTf})_{3}\right]_{2 .}{ }^{15}$

The emissive ${ }^{2} \mathrm{E}_{\mathrm{g}}$ state is energetically only ca. $650 \mathrm{~cm}^{-1}$ below the ${ }^{2} T_{1 g}$ excited state, and consequently the latter is thermally populated at room temperature, leading to additional ${ }^{2} \mathrm{~T}_{1 \mathrm{~g}} \rightarrow{ }^{4} \mathrm{~A}_{2 \mathrm{~g}}$ emission at $738 \mathrm{~nm}$. Temperature variation changes the intensity ratio between $738\left({ }^{2} \mathrm{~T}_{1 \mathrm{~g}}\right)$ and $775 \mathrm{~nm}\left({ }^{2} \mathrm{E}_{\mathrm{g}}\right)$ luminescence, and $\left[\mathrm{Cr}(\mathrm{ddpd})_{2}\right]^{3+}$ can therefore be used as a molecular ratiometric thermometer between 210 and $373 \mathrm{~K}$ in aqueous solution. ${ }^{16}$ The strong ligand field keeps thermal population of the nonradiatively relaxing ${ }^{4} \mathrm{~T}_{2 \mathrm{~g}}$ state inefficient. Aside from these favorable variable-temperature emission properties, $\left[\mathrm{Cr}(\mathrm{ddpd})_{2}\right]^{3+}$ exhibits unusual pressure-dependent luminescence. Its ${ }^{2} \mathrm{E}_{\mathrm{g}} \rightarrow{ }^{4} \mathrm{~A}_{2 \mathrm{~g}}$ emission red-shifts by up to 14.8 $\mathrm{cm}^{-1} / \mathrm{kbar}$, exceeding the pressure-induced shift in ruby by a factor of $20 .{ }^{12}$ The $\left[\mathrm{Cr}(\mathrm{ddpd})_{2}\right]^{3+}$ complex is a good sensitizer of ${ }^{1} \mathrm{O}_{2}$ via energy transfer whilst concurrent photoinduced electron transfer to $\mathrm{O}_{2}$ is less important, enabling the selective $\alpha-\mathrm{CH}$ activation of amines by ${ }^{1} \mathrm{O}_{2}{ }^{17}$

Photochemical investigations based on electron transfer were recently performed by the groups of Ferreira and Shores. ${ }^{13}$ Their initial studies concentrated on the application of the $\left[\mathrm{Cr}\left(\mathrm{ph}_{2} \mathrm{phen}\right)_{3}\right]^{3^{+}}$complex $\left(\mathrm{ph}_{2} \mathrm{phen}=4,7^{-}\right.$ diphenyl-1,10-phenthroline) as a catalyst for radicalcation-mediated Diels-Alder cycloadditions (Figure 2c). The excited-state oxidation potential of this complex is high (1.40 V vs. SCE), and the ${ }^{2} \mathrm{E}$ excited-state lifetime is very long $(425 \mu$ s in $1 \mathrm{M}$ aq. $\mathrm{HCl}) .{ }^{18}$ Irradiation 
Table 2. Valence electron configurations and photophysical properties of some $3 d^{3}, 3^{d^{5}}$ and $3 d^{6}$ metal complexes.

\begin{tabular}{|c|c|c|c|c|c|}
\hline & config. & $\lambda_{\max }{ }^{a}$ & $\tau^{a}$ & $\phi^{a}$ & exc. state \\
\hline$\left[\mathrm{Cr}(\mathrm{ddpd})_{2}\right]^{3+}$ & $3 \mathrm{~d}^{3}$ & $775 \mathrm{~nm}^{b}$ & $898 \mu \mathrm{s}^{b} / 2.3 \mathrm{~ms}^{c}$ & $0.11^{b} / 0.30^{c}$ & ${ }^{2} \mathrm{E}_{\mathrm{g}}$ \\
\hline$\left[\mathrm{Cr}\left(\mathrm{ph}_{2} \text { phen }\right)_{3}\right]^{3^{+}}$ & $3 d^{3}$ & $744 \mathrm{~nm}^{d}$ & $425 \mu \mathrm{s}^{d}$ & $0.03^{d}$ & ${ }^{2} \mathrm{E}$ \\
\hline$[(\mathrm{Bn}-\mathrm{TPEN}) \mathrm{Mn}(\mathrm{O})]^{2+-}\left[\mathrm{Sc}(\mathrm{OTf})_{3}\right]_{2}$ & $3 d^{3}$ & & $6.4 \mu \mathrm{s}^{e}$ & & ${ }^{2} \mathrm{E}$ \\
\hline$\left[\mathrm{Cr}\left(\mathrm{CN}^{\mathrm{tBu}} \mathrm{Ar}_{3} \mathrm{NC}\right)_{3}\right]$ & $3 \mathrm{~d}^{6}(\mathrm{ls})$ & $630 \mathrm{~nm}^{f}$ & $2.2 \mathrm{~ns}^{f}$ & $10^{-5 f}$ & 3MLCT \\
\hline$\left[\mathrm{Fe}\left(\mathrm{im}^{\mathrm{Me}}-\mathrm{py}^{\mathrm{H}}-\mathrm{im}^{\mathrm{Me}}\right)_{3}\right]^{2+}$ & $3 d^{6}(1 s)$ & - & $9 \mathrm{ps}^{g}$ & $\mathrm{o}$ & $3 \mathrm{MLCT}$ \\
\hline$\left[\mathrm{Fe}\left(\mathrm{im}^{\mathrm{Me}}-\mathrm{py}^{\mathrm{COOH}}-\mathrm{im}^{\mathrm{Me}}\right)_{3}\right]^{2+}$ & $3 d^{6}(1 s)$ & - & $16 \mathrm{ps}^{h} / 18 \mathrm{ps}^{i}$ & $\mathrm{o}$ & $3 \mathrm{MLCT}$ \\
\hline$\left[\mathrm{Fe}\left(\mathrm{bzim}^{\mathrm{Me}}-\mathrm{py}^{\mathrm{COOH}} \text {-bzim }{ }^{\mathrm{Me}}\right)_{3}\right]^{2+}$ & $3 \mathrm{~d}^{6}(\mathrm{ls})$ & - & $26 \mathrm{ps}^{h}$ & $\mathrm{o}$ & 3MLCT \\
\hline$\left[\mathrm{Fe}\left(\mathrm{im}^{\mathrm{iPr}}-\mathrm{py}^{\mathrm{H}}-\mathrm{im}^{\mathrm{iPr}}\right)_{3}\right]^{2+}$ & $3 d^{6}(1 s)$ & - & $8.1 \mathrm{ps}^{k}$ & o & $3 \mathrm{MLCT}$ \\
\hline$\left[\mathrm{Fe}\left(\mathrm{im}^{\mathrm{tBu}}-\mathrm{py}^{\mathrm{H}}-\mathrm{im}^{\mathrm{tBu}}\right)_{3}\right]^{2+}$ & $3 d^{6}(\mathrm{ls})$ & - & $260 \mathrm{ps}^{l}$ & $\mathrm{o}$ & $5 \mathrm{~T}_{2 \mathrm{~g}}$ \\
\hline$\left[\mathrm{Fe}(\mathrm{dcpp})_{2}\right]^{2+}$ & $3^{6}(1 \mathrm{~s})$ & - & $280 \mathrm{ps}^{m}$ & $\mathrm{o}$ & $3 \mathrm{~T}_{1 \mathrm{~g}}$ \\
\hline$\left[\mathrm{Fe}(\text { dctpy })_{2}\right]^{2+}$ & $3 d^{6}(\mathrm{hs})$ & - & $16 \mathrm{ps}^{n}$ & $\mathrm{o}$ & 5/7MLCT \\
\hline$\left[\mathrm{Fe}(\mathrm{btz})_{3}\right]^{2+}$ & $3 \mathrm{~d}^{6}(\mathrm{ls})$ & - & $528 \mathrm{ps}^{\circ}$ & $\mathrm{o}$ & $3 \mathrm{MLCT}$ \\
\hline$\left[\mathrm{Fe}(\mathrm{btz})_{3}\right]^{3^{+}}$ & 3d5 (ls) & $600 \mathrm{~nm}^{p}$ & $100 \mathrm{ps}^{p}$ & $3 \cdot 10^{-4} p$ & ${ }^{2} \mathrm{LMCT}$ \\
\hline$\left[\mathrm{Co}(\text { dgpy })_{2}\right]^{3+}$ & $3 d^{6}(1 s)$ & $440 \mathrm{~nm}^{q}$ & $5.07 \mathrm{~ns}^{q}$ & $0.007^{q}$ & $3 \mathrm{LMCT}$ \\
\hline$\left[\mathrm{Co}(\mathrm{dgpz})_{2}\right]^{3+}$ & $3 \mathrm{~d}^{6}(\mathrm{ls})$ & $412 \mathrm{~nm}^{q}$ & $3.21 \mathrm{~ns} / 8.69 \mathrm{~ns}^{q}$ & $0.004^{q}$ & $3 \mathrm{LMCT}$ \\
\hline
\end{tabular}

${ }^{a}$ In $\mathrm{CH}_{3} \mathrm{CN}$ at room temperature unless otherwise noted; ${ }^{b}$ in deaearated $\mathrm{H}_{2} \mathrm{O} ;{ }^{8}{ }^{c}$ in $\mathrm{Ar}$-saturated $\mathrm{CD}_{3} \mathrm{CN} ; 9^{d}$ in $1 \mathrm{M}$ aq. $\mathrm{HCl} ;{ }^{18} e$ in TFE/MeCN; ${ }^{15} f$ in de-aerated THF; ${ }^{14} g$ from ref. ${ }^{19} ;{ }^{h}$ from ref. ${ }^{20} ;{ }^{i}$ from ref. ${ }^{21} ;{ }^{k}$ from ref. ${ }^{22} ;{ }^{l}$ from ref. ${ }^{23} ;{ }^{m}$ from ref. ${ }^{24 ;}{ }^{n}$ from ref. ${ }^{25}$; ${ }^{\circ}$ from ref. ${ }^{26}$; ${ }^{p}$ from ref. ${ }^{27}$; ${ }^{q}$ from ref. ${ }^{28}$. ( $\lambda_{\max }=$ emission band maximum; MLCT = metal-to-ligand charge transfer; $\mathrm{LMCT}=$ ligand-to-metal charge transfer).

into $\pi-\pi^{*}$ absorption bands between 300 and $419 \mathrm{~nm}$ promotes $[4+2]$ cycloaddition reactions with a range of different substrates, and the authors noted that this represents the first application of $\mathrm{Cr}(\mathrm{III})$ complexes as photocatalysts in organic synthesis. ${ }^{13}$ Electron-rich dienophiles were investigated initially, but subsequent work demonstrated that electron-deficient dienophiles also yield cycloaddition products. ${ }^{29}$ In-depth mechanistic studies revealed that ${ }^{1} \mathrm{O}_{2}$ and $\mathrm{O}_{2}{ }^{-}$intermediates both play key roles in these light-driven cycloadditions. ${ }^{30}$ Due to its high oxidizing power in its very long-lived excited state, the $\left[\mathrm{Cr}\left(\mathrm{ph}_{2} \text { phen }\right)_{3}\right]^{3+}$ complex is likely to remain attractive for photoredox catalysis. ${ }^{31}$

Whilst $\mathrm{Cr}(\mathrm{III})$ is a prototype spin-flip d-d emitter, $\mathrm{Cr}(\mathrm{o})$ can be stabilized in complexes representing classical MLCT luminophores. We recently found that a chelating diisocyanide ligand with a terphenyl backbone $\left(\mathrm{CN}^{\mathrm{tBu}}\right.$ $\mathrm{Ar}_{3} \mathrm{NC}$ ) can be used to obtain the homoleptic $\left[\mathrm{Cr}\left(\mathrm{CN}^{\mathrm{tBu}} \mathrm{Ar}_{3} \mathrm{NC}\right)_{3}\right]$ complex which emits from a $3 \mathrm{MLCT}$ state (Figure 2d). ${ }^{14}$ The luminescence lifetime of this lowspin $3 \mathrm{~d}^{6}$ complex is short $(2.2 \mathrm{~ns}$ in de-aerated THF at 20 ${ }^{\circ} \mathrm{C}$, Table 2) and its quantum yield is low $\left(10^{-5}\right)$, yet the mere observation of emission is noteworthy given the fact that related isoelectronic $\mathrm{Fe}(\mathrm{II})$ complexes are generally non-luminescent. Presumably, the metal-centered $3 \mathrm{~d}-\mathrm{d}$ and ${ }^{5} \mathrm{~d}-\mathrm{d}$ excited states leading to very rapid non-radiative relaxation in $\mathrm{Fe}(\mathrm{II})$ compounds (Figure 3) are raised in energy in the strong ligand field of the arylisocyanides, making radiative relaxation from the lowest ${ }^{3} \mathrm{MLCT}$ state competitive. ${ }^{32}$ The $\left[\mathrm{Cr}\left(\mathrm{CN}^{\mathrm{tBu}} \mathrm{Ar}_{3} \mathrm{NC}\right)_{3}\right]$ complex has been used successfully as a sensitizer for triplet-triplet annihi- lation upconversion, showing that its excited-state lifetime is long enough for bimolecular reactions. ${ }^{14}$

Whilst photoluminescence from $\mathrm{Mn}$ (II) is a common phenomenon in the solid state, emission from discrete $\mathrm{Mn}(\mathrm{II})$ complexes in fluid solution at room temperature is rare. A recent study claims that a mononuclear $\mathrm{Mn}$ (II) complex exhibits excitation wavelength-dependent emission in fluid solution. 33 For a polynuclear Mn(II) compound the situation is much less convoluted, and orange emission was unambiguously observable in DMF at room temperature. 34

A bis-(tris(carbene)borate) manganese(IV) complex was found to exhibit ${ }^{2} \mathrm{E} \rightarrow{ }^{4} \mathrm{~A}_{2}$ emission at $828 \mathrm{~nm}$ in the solid state at $80 \mathrm{~K}$, and in addition this complex emitted from an LMCT state under the same conditions. ${ }^{35}$ The perhaps most spectacular recent example of a photoactive $\mathrm{Mn}$ (IV) complex was reported by the groups of Fukuzumi and Nam who discovered that a Mn(IV)-oxo complex binding $\mathrm{Sc}^{3+}$ ions (Figure 2e) is capable of hydroxylating benzene under photoirradiation. ${ }^{15}$ This $[(\mathrm{Bn} \text {-TPEN }) \mathrm{Mn}(\mathrm{O})]^{2+}$ $\left[\mathrm{Sc}(\mathrm{OTf})_{3}\right]_{2}$ complex exhibits a ${ }^{2} \mathrm{E}$ state ca. $0.7 \mathrm{eV}$ above the ground state with a lifetime of $6.4 \mu \mathrm{s}$ in a mixture of trifluoroethanol and $\mathrm{MeCN}$ at room temperature. Benzene quenches this ${ }^{2} \mathrm{E}$ state with a rate constant of $5.6 \cdot 10^{5}$ $\mathrm{M}^{-1} \mathrm{~s}^{-1}$, and benzene dimer radical cation is formed. In presence of water, this can be exploited for the hydroxylation of benzene. ${ }^{15}$

$\mathrm{Mn}$ is much more abundant than $\mathrm{Cu}$ and $\mathrm{Cr}$ (Table 1 ), yet there has been comparatively little work on discrete $\mathrm{Mn}$ complexes emitting in fluid solution. 
(a)
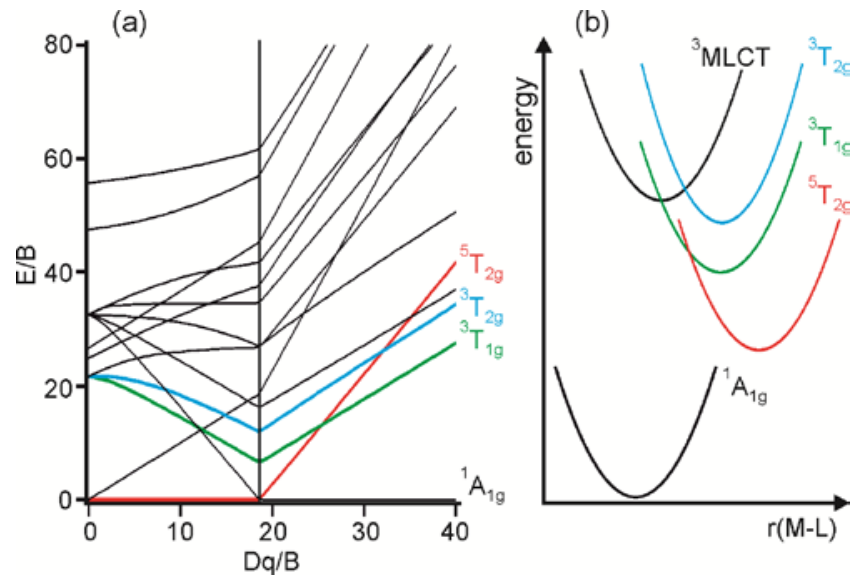

Figure 3. (a) Tanabe-Sugano diagram for the $d^{6}$ electron configuration (in $\mathrm{O}_{\mathrm{h}}$ symmetry) and (b) schematic representation of the key potential energy wells for $3 \mathrm{~d}^{6} \mathrm{Fe}(\mathrm{II})$ and $\mathrm{Cr}(\mathrm{o})$ complexes. ${ }^{32,36}$

\section{IRON AND COBALT}

The search for luminescent $\mathrm{Fe}(\mathrm{II})$ complexes as $3 \mathrm{~d}^{6}$ analogues of emissive $\left[\mathrm{Ru}(\alpha \text {-diimine })_{3}\right]^{2+}$ compounds continues to be a central theme in coordination chemistry. In the past few years, N-heterocyclic carbenes received much attention because they tend to impose strong ligand fields due to their $\sigma$-donor properties. ${ }^{37}$ As noted above for isoelectronic $\mathrm{Cr}(\mathrm{o}),{ }^{14}$ this is beneficial because it raises the energy of non-radiatively deactivating ${ }^{3} \mathrm{~d}-\mathrm{d}$ and $5 \mathrm{~d}$-d excited states (Figure 3). Closely related Fe(II) NHC complexes were reported by different groups. The $\left[\mathrm{Fe}\left(\mathrm{im}^{\mathrm{Me}}-\mathrm{py}^{\mathrm{H}}-\mathrm{im}^{\mathrm{Me}}\right)_{3}\right]^{2+}$ complex (Figure $4 \mathrm{a}$ ) reported by the groups of Wärnmark and Sundström was the first homoleptic $\mathrm{Fe}$ (II) NHC complex to be investigated for its photophysical properties. ${ }^{19}$ Transient absorption studies revealed a ${ }^{3}$ MLCT lifetime of 9 ps (Table 2), but there is no emission.

Later, the $\left[\mathrm{Fe}\left(\mathrm{im}^{\mathrm{Me}}-\mathrm{py}^{\mathrm{COOH}_{-} \mathrm{im}}{ }^{\mathrm{Me}}\right)_{3}\right]^{2+}$ and $\left[\mathrm{Fe}\left({ }^{\mathrm{Me}}\right.\right.$ bzimpy ${ }^{\mathrm{COOH}}-$ bzim $\left.\left.^{\mathrm{Me}}\right)_{3}\right]^{2+}$ complexes were reported by the teams of Gros and Haacke (Figure 4a/b) to have ${ }^{3}$ MLCT lifetimes of 16 and 26 ps, respectively, (Table 2). ${ }^{20}\left[\mathrm{Fe}\left(\mathrm{im}^{\mathrm{Me}}-\mathrm{py}^{\mathrm{COOH}_{-}}\right.\right.$ $\left.\left.\mathrm{im}^{\mathrm{Me}}\right)_{3}\right]^{2+}$ was synthesized independently by Wärnmark and coworkers, and a ${ }^{3}$ MLCT lifetime of 18 ps was reported. ${ }^{21}$ These unusually long lifetimes are attributable to smaller energy differences between MLCT and d-d excited states when compared to previously studied Fe(II) polypyridyl complexes, making nonradiative relaxation via $\mathrm{d}$-d states less efficient. These findings demonstrate the usefulness of the design principle of employing strongly $\sigma$-donating NHC ligands, as pointed out already in the initial study by Wärnmark and Sundström, ${ }^{19}$ as well as in several of their later works. ${ }^{36,38}$

Nonradiative relaxation in fac- and mer-isomers of iron(II) $\mathrm{NHC}$ complexes with a similar $\mathrm{FeN}_{2} \mathrm{C}_{4}$ primary coordination sphere were found to be different in that the mer-isomer showed a steeper path toward the $3 \mathrm{~d}-\mathrm{d}$ minimum than the $f a c$-isomer. ${ }^{39}$ Furthermore, elongation of the $\mathrm{Fe}-\mathrm{N}$ distance was identified as a main contributor to nonradiative excited-state decay. The $\left[\mathrm{Fe}\left(\mathrm{im}^{\mathrm{Me}}-\mathrm{py}^{\mathrm{COOH}}\right.\right.$
$\left.\left.\mathrm{im}^{\mathrm{Me}}\right)_{3}\right]^{2+}$ complex (Figure 4a) was used by the team lead by Wärnmark, Sundström and Persson in dye-sensitized $\mathrm{TiO}_{2}$ solar cells. ${ }^{21}$ Injection of ${ }^{3} \mathrm{MLCT}$-excited electrons into the semiconductor occurred with a time constant of $3.1 \mathrm{ps}$, and an impressive $92 \%$ yield for conversion of photons into photoelectrons was achieved. This became possible due to the comparatively long ${ }^{3} \mathrm{MLCT}$ lifetime of 37 ps for this complex (measured on $\mathrm{Al}_{2} \mathrm{O}_{3}$ support).

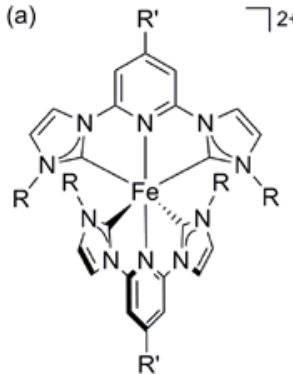

(c)

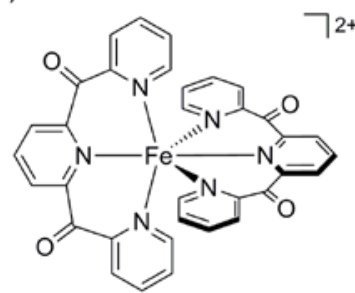

(e)

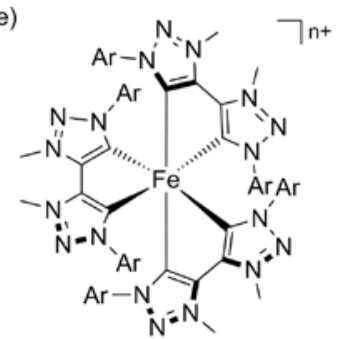

(b)

$\mathrm{R}^{\prime} \quad 72+$

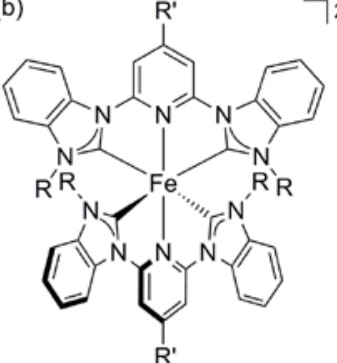

(d)

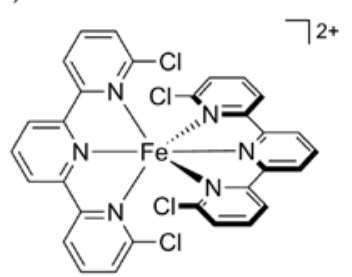

(f)

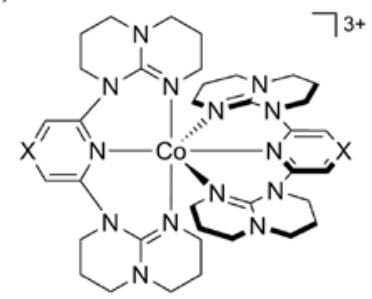

Figure 4. Molecular structures of Fe and Co complexes: (a) $\mathrm{R}=\mathrm{Me}, \mathrm{R}^{\prime}=\mathrm{H}:\left[\mathrm{Fe}\left(\mathrm{im}^{\mathrm{Me}}-\mathrm{py}^{\mathrm{H}_{-}}-\mathrm{im}^{\mathrm{Me}}\right)_{3}\right]^{2+, 19} \mathrm{R}=\mathrm{Me}, \mathrm{R}^{\prime}=\mathrm{COOH}$ : $\left[\mathrm{Fe}\left(\mathrm{im}^{\mathrm{Me}}-\mathrm{py}^{\mathrm{COOH}}-\mathrm{im}^{\mathrm{Me}}\right)_{3}\right]^{2+}{ }_{;}{ }^{\text {oad }},{ }_{21} \mathrm{R}={ }^{i} \mathrm{Pr}, \mathrm{R}^{\prime}=\mathrm{H}$ : $\left[\mathrm{Fe}\left(\mathrm{im}^{\mathrm{iPr}}-\mathrm{py}^{\mathrm{H}}-\right.\right.$ $\left.\left.\mathrm{im}^{\mathrm{iPr}}\right)_{3}\right]^{2+; 22} \mathrm{R}={ }^{t} \mathrm{Bu}, \mathrm{R}^{\prime}=\mathrm{H}:\left[\mathrm{Fe}\left(\mathrm{im}^{\mathrm{tBu}}-\mathrm{py}^{\mathrm{H}}-\mathrm{im}^{\mathrm{tBu}}\right)_{3}\right]^{2+; 23}$ (b) $\mathrm{R}=$ Me, R' $=\mathrm{COOH}:\left[\mathrm{Fe}\left(\text { bzim }^{\mathrm{Me}}-\mathrm{py}^{\mathrm{COOH}}-\mathrm{bzzim}_{\mathrm{Me}}\right)_{3}\right]^{2+} ;$ 2ob (c) $\left[\mathrm{Fe}(\mathrm{dcpp})_{2}\right]^{2+; 24}$ (d) $\left.\mathrm{Fe}(\mathrm{dctpy})_{2}\right]^{2+; 25}$ (e) $\left[\mathrm{Fe}(\mathrm{btz})_{3}\right]^{\mathrm{n}+}\left(\mathrm{n}=2^{26}\right.$, $\left.{ }^{38 b}, \mathrm{n}=3^{27}\right) ;(\mathrm{f})\left[\mathrm{Co}(\mathrm{dgpy})_{2}\right]^{3+}(\mathrm{X}=\mathrm{CH})$ and $\left[\mathrm{Co}(\mathrm{dgpz})_{2}\right]^{3+}(\mathrm{X}=$ N). ${ }^{28}$

Bauer, Lochbrunner and coworkers performed systematic studies and established a correlation between the NHC donor count and the ${ }^{3}$ MLCT lifetime, with a maximum of $8.1 \mathrm{ps}$ for $\left[\mathrm{Fe}\left(\mathrm{im}^{\mathrm{iPr}}-\mathrm{py}^{\mathrm{H}}-\mathrm{im}^{\mathrm{iPr}}\right)_{3}\right]^{2+}$ (Figure 4a) among their series of $\mathrm{FeN}_{2} \mathrm{C}_{4}$ complexes. ${ }^{22}$ Whilst the destabilization of $3 \mathrm{~d}-\mathrm{d}$ and $5 \mathrm{~d}-\mathrm{d}$ states plays a key role, ${ }^{36}$ this is not the only important factor. Recent time-resolved Xray studies confirmed that the ${ }^{5} \mathrm{~d}-\mathrm{d}$ state in $\left[\mathrm{Fe}\left(\mathrm{im}^{\mathrm{tBu}}-\mathrm{py}^{\mathrm{H}}-\right.\right.$ $\left.\left.\mathrm{im}^{\mathrm{tBu}}\right)_{3}\right]^{2+}$ (Figure 4a) exhibits very large differences in metal-ligand bond lengths relative to the ground state, ${ }^{23}$ even when compared to classical Fe(II) spin crossover compounds..$^{40}$ 
Table 3. Photophysical properties of some $3 \mathrm{~d}^{10}$ metal complexes.

\begin{tabular}{|c|c|c|c|c|}
\hline & $\lambda_{\max }{ }^{a}$ & $\tau^{a}$ & $\phi^{a}$ & exc. state \\
\hline$\left[\mathrm{Ni}\left(\mathrm{CNAr}_{5} \mathrm{NC}\right)_{2}\right]$ & $510 \mathrm{~nm}^{b}$ & $0.2 / 1.1 \mu \mathrm{s}^{b}$ & - & 3MLCT \\
\hline$\left[\mathrm{Ni}\left(\mathrm{CNAr}_{5}{ }^{\text {(th) }} \mathrm{NC}\right)_{2}\right]$ & $560 \mathrm{~nm}^{b}$ & $0.23 / 1.2 \mu \mathrm{s}^{b}$ & - & $3 \mathrm{MLCT}$ \\
\hline$\left[\mathrm{Cu}(\mathrm{dpp})_{2}\right]^{+}$ & $700 \mathrm{~nm}^{c}$ & $250 \mathrm{~ns}^{c}$ & $0.001^{c}$ & $3 \mathrm{MLCT}$ \\
\hline$[\mathrm{Cu}(\mathrm{dbp})(\mathrm{POP})]^{+}$ & $560 \mathrm{~nm}^{d}$ & $16.1 \mu \mathrm{s}^{d}$ & $0.16^{d}$ & 3MLCT \\
\hline$\left[\mathrm{Cu}(\mathrm{cbz})\left(\mathrm{P}(m-\mathrm{tol})_{3}\right)_{2}\right]$ & $415 \mathrm{~nm}^{e}$ & & - & \\
\hline$\left[\mathrm{Cu}\left(\mathrm{SAr}^{\mathrm{Me} 2}\right)_{2}\right]^{-}$ & $675 \mathrm{~nm}^{f}$ & $7 \mu \mathrm{s} f$ & - & \\
\hline$\left[\mathrm{Cu}\left(\mathrm{R}_{\mathrm{n}} \mathrm{B}=\mathrm{BR} \mathrm{R}_{\mathrm{n}}\right) \mathrm{Cl}\right]$ & $417 \mathrm{~nm}^{g}$ & $2.47 \mathrm{~ns}^{g}$ & $0.18^{g}$ & ${ }^{1} \mathrm{ILCT}$ \\
\hline$\left[\left(\mathrm{B}_{2} \mathrm{IDip}_{2}\right)(\mathrm{CuCl})_{3}\right]$ & $637 \mathrm{~nm}^{h}$ & $26.45 \mu \mathrm{s}^{h}$ & $0.29^{h}$ & 3ILCT/3MLCT \\
\hline$\left[(\mathrm{DAC})_{2} \mathrm{Cu}\right]^{+}$ & $490 \mathrm{~nm}^{i}$ & $18 \mu \mathrm{s}^{i}$ & $0.65^{i}$ & 3IL \\
\hline$[\mathrm{Cu}(\mathrm{dtpb}) \mathrm{I}]$ & $517 \mathrm{~nm}^{k}$ & $6.5 \mu \mathrm{s}^{k}$ & $0.60^{k}$ & \\
\hline$[(\mathrm{PNP}) \mathrm{Cu}]_{2}$ & $500 \mathrm{~nm}^{l}$ & $10.2 \mu \mathrm{s}^{l}$ & $0.68^{l}$ & \\
\hline$\left[\mathrm{Zn}_{4} \mathrm{O}(\text { pyrpy })_{6}\right]$ & $455 \mathrm{~nm}^{m}$ & $15 \mathrm{~ns}^{m}$ & $0.66^{m}$ & ${ }^{1} \mathrm{IL}$ \\
\hline$\left[(\mathrm{PN})_{2} \mathrm{Zn}\right]$ & $455 \mathrm{~nm}^{n}$ & $<10 \mathrm{~ns}^{n}$ & $0.088^{n}$ & \\
\hline$[(\mathrm{PNNP}) \mathrm{Zn}]_{2}$ & $537 \mathrm{~nm}^{\circ}$ & $2.8 \mathrm{~ns} / 0.13 \mathrm{~ns}^{\circ}$ & $0.93^{\circ}$ & $\mathrm{LC}$ \\
\hline
\end{tabular}

${ }^{a}$ In $\mathrm{CH}_{3} \mathrm{CN}$ at room temperature unless otherwise noted; ${ }^{b}$ in frozen toluene at $77 \mathrm{~K} ; 4^{4}$ in deaerated $\mathrm{CH}_{2} \mathrm{Cl}_{2} ; 42 d$ in $\mathrm{CH}_{2} \mathrm{Cl}_{2} ; 43 \mathrm{e}$ from ref. ${ }^{44} ; f$ from ref. ${ }^{45} ; g$ in toluene; $46 h$ in toluene; $47{ }^{i} \mathrm{CH}_{2} \mathrm{Cl}_{2}$ under $\mathrm{N}_{2} ;{ }^{4}{ }^{k}$ in $\mathrm{CH}_{2} \mathrm{Cl}_{2} ; 49 ;{ }^{l}$ in cyclohexane;50 $m$ in $\mathrm{CH}_{2} \mathrm{Cl}_{2} ; 5^{1} n$ in benzene; $5^{\circ}$ in $\mathrm{C}_{6} \mathrm{D}_{6}$ or $\mathrm{C}_{7} \mathrm{D}_{8} .53$ (ILCT = intraligand charge transfer; IL = intraligand excitation).

Structural aspects were also in the focus of several investigations of non-NHC $\mathrm{Fe}(\mathrm{II})$ complexes with more classical tpy-related ligands. In McCusker's $\left[\mathrm{Fe}(\mathrm{dcpp})_{2}\right]^{2+}$ the coordination geometry of the metal center is in nearly perfectly octahedral geometry (Figure 4c), ${ }^{24}$ reminiscent of the situation in $\left[\mathrm{Cr}(\mathrm{ddpd})_{2}\right]^{3+}$ (Figure 2a). ${ }^{8}$ The resulting enhanced directionality of the metal-ligand orbital overlap in combination with the low energy of the ligand $\pi^{*}$ orbitals (caused by the carbonyl groups in the backbone) leads to increased stabilization of the metal $t_{2 g}$ orbitals and a consequent increase in ligand field strength by ca. $600 \mathrm{meV}$ compared to $\left[\mathrm{Fe}(\text { tpy })_{2}\right]^{2+}$. This results in a situation in which the energetic order of the lowest ${ }^{3} \mathrm{~d}-\mathrm{d}$ and ${ }^{5} \mathrm{~d}$-d states is likely reversed (Figure $3 \mathrm{a}$ ). Usually the ${ }^{5} \mathrm{~d}-\mathrm{d}$ $\left(5 \mathrm{~T}_{2 \mathrm{~g}}\right)$ state is lowest (Figure $3 \mathrm{~b}$ ), but for $\left[\mathrm{Fe}(\mathrm{dcpp})_{2}\right]^{2+}$ the observable excited-state lifetime of $28 \mathrm{o}$ ps is possibly due to the $3 \mathrm{~d}-\mathrm{d}\left(3 \mathrm{~T}_{1 \mathrm{~g}}\right)$ state (Table 2$)$. The $\left[\mathrm{Fe}(\mathrm{dctpy})_{2}\right]^{2+} \mathrm{com}-$ plex (Figure $4 \mathrm{~d}$ ) is another example where structural aspects play a central role. ${ }^{25}$ In an attempt to decelerate non-radiative relaxation, the dctpy ligand was designed by Damrauer and coworkers to hinder interligand relative motions leading to coupling between MLCT and d-d manifolds. The resulting complex has a high-spin configuration in the ground state, and this permits spin-allowed excitation into a ${ }^{5} \mathrm{MLCT}$ state. The ultimate photoproduct is either a ${ }^{5} \mathrm{MLCT}$ or ${ }^{7} \mathrm{MLCT}$ excited state which decays with a lifetime of $16 \mathrm{ps}$ in fluid solution. ${ }^{25}$ Investigations of analogous complexes where the chloro-substituents on the tpy ligand were replaced by $\mathrm{F}$ or $\mathrm{Br}$ support the view that interligand steric interactions can be exploited to slow non-radiative relaxation. ${ }^{54}$

Some of the most remarkable advances regarding iron photophysics were made recently with mesoionic car- benes such as bis(1,2,3-triazol-5-ylidine) (btz). ${ }^{38 \mathrm{~b}}$ This ligand class is even more strongly $\sigma$-donating than normal $\mathrm{NHCs}$, and the increased number of $\mathrm{N}$-atoms leads to favorably low-lying $\pi^{*}$ orbitals. Indeed, the $\left[\mathrm{Fe}(\mathrm{btz})_{3}\right]^{2+}$ complex (Figure 4e) exhibits a ${ }^{3} \mathrm{MLCT}$ excited state with a record lifetime of 528 ps in $\mathrm{CH}_{3} \mathrm{CN}$ at room temperature, yet no emission was reported. ${ }^{26}$ Its one-electron oxidized form, $\left[\mathrm{Fe}(\mathrm{btz})_{3}\right]^{3+}$, exhibits even more spectacular behavior. This $3 \mathrm{~d}^{5}$ complexes luminesces from a ${ }^{2} \mathrm{LMCT}$ excited state with a lifetime of $100 \mathrm{ps}$ and a quantum yield of $3 \cdot 10^{-4}$ in $\mathrm{CH}_{3} \mathrm{CN}$ (Table 2). ${ }^{27}$ This emission is spin-allowed, making radiative relaxation very competitive with nonradiative events, and moreover the potential ${ }^{4} \mathrm{~d}-\mathrm{d}$ and ${ }^{6} \mathrm{~d}-$ $\mathrm{d}$ acceptor states are high in energy at the relaxed ${ }^{2} \mathrm{LMCT}$ $\mathrm{FeC}_{6}$ coordination geometry.

$\mathrm{Co}(\mathrm{III})$ has the same d-electron count as $\mathrm{Fe}(\mathrm{II})$, and given the challenges associated with obtaining luminescent $\mathrm{Fe}(\mathrm{II})$ complexes and the promising results reported for isoelectronic $\mathrm{Cr}(\mathrm{o}),{ }^{14}$ exploration of $\mathrm{Co}(\mathrm{III})$ compounds seems fundamentally interesting. The groups of ZysmanColman and Hanan synthesized the $\left[\mathrm{Co}(\mathrm{dgpy})_{2}\right]^{3+}$ and $\left[\mathrm{Co}(\mathrm{dgpz})_{2}\right]^{3^{+}}$complexes (Figure $\left.4 \mathrm{f}\right)$ and found that they emit blue ${ }^{3} \mathrm{LMCT}$ emission following excitation in the low-energy UV region. ${ }^{28}$ Luminescence quantum yields and excited-state lifetimes are much higher than in the $\mathrm{Cr}(\mathrm{o})$ case (Table 2). ${ }^{14}$ Moreover, these Co(III) complexes are very strong photooxidants that can be used for the trifluoromethylation of polycyclic aromatic hydrocarbons. ${ }^{28}$ Arene $\mathrm{C}-\mathrm{H}$ trifluoromethylation recently became possible via photoinduced homolysis of a $\mathrm{Co}(\mathrm{III})-\mathrm{CF}_{3}$ bond. ${ }^{55}$ The groups of Fukuzumi and Nam reported on a $\mathrm{Co}(\mathrm{IV})$-oxygen complex that was able to engage in electron transfer with $m$-xylene and anisole. ${ }^{5}$ Excited state 
electron transfer from cobalt complexes anchored to $\mathrm{TiO}_{2}$ has been reviewed. 57

\section{NICKEL}

Photoactive $\mathrm{Ni}(\mathrm{II})$ complexes are receiving much more attention since it was found that nickel catalysis cycles can involve photoexcited $\mathrm{Ni}$ intermediates..$^{8}$ The groups of MacMillan and McCusker demonstrated that the $\left[\mathrm{Ni}\left(\mathrm{MeO}_{\mathrm{bpy}}\right)\left(\mathrm{Ar}^{\mathrm{CF}_{3}}\right)(\mathrm{OCOMe})\right]$ complex (Figure 5a), an isolable model compound for relevant intermediates in Ni-mediated coupling reactions, can undergo reductive elimination via the intermediacy of a $\mathrm{Ni}(\mathrm{II})$ excited state. 59 When suitable sensitizers are present, such excited states can be formed via triplet energy transfer. Whilst for this particular complex a d-d state was considered the lowestenergy excited state responsible for the photochemistry, the groups of Doyle and Scholes came to a different conclusion for a structurally related $\mathrm{Ni}(\mathrm{II})$ aryl halide complex. ${ }^{60}$ For $\left[\mathrm{Ni}\left({ }^{\mathrm{BB} u} \mathrm{bpy}\right)\left(\mathrm{Ar}{ }^{\mathrm{Me}}\right)(\mathrm{Cl})\right]$ (Figure $\left.5 \mathrm{~b}\right)$, transient absorption studies revealed a ${ }^{3}$ MLCT state with a lifetime of $4.1 \mathrm{~ns}$ in fluid solution, and that $3 \mathrm{MLCT}$ state readily engaged in bimolecular electron transfer reactions. 3 MLCT relaxation seems to be essentially non-radiative in this case. Similarly, the $[\mathrm{Ni}(\mathrm{Mabiq})]^{+}$complex (Figure 5c) explored by Hess and Bach is non-luminescent, yet its photoexcitation promotes photocatalytic $\mathrm{C}-\mathrm{C}$ bond formation in presence of sacrificial reductants. ${ }^{61}$ The HOMO-LUMO transition in this case has predominantly LLCT character, but contributions from d-d and MLCT transitions seem non-negligible.
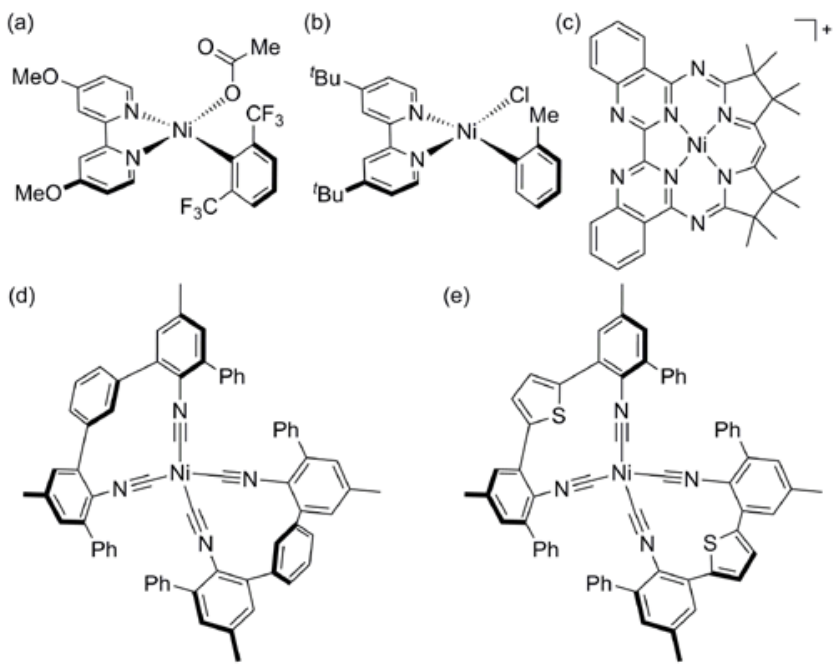

(e)

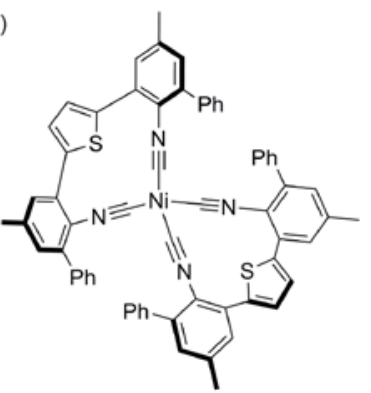

Figure 5. Molecular structures of $\mathrm{Ni}$ complexes: (a) $\left[\mathrm{Ni}\left(\mathrm{MeO}_{\mathrm{bpy}}\right)\left(\mathrm{Ar}^{\mathrm{CF}} 3\right)(\mathrm{OCOMe})\right] ; 59$ (b) $\left[\mathrm{Ni}\left(\mathrm{tBu}_{\mathrm{Bby}}\right)\left(\mathrm{Ar}^{\mathrm{Me}}\right)(\mathrm{Cl})\right] ; 60$
(c) $\quad[\mathrm{Ni}(\mathrm{Mabiq})]^{+} ; 61$
(d)
$\left[\mathrm{Ni}\left(\mathrm{CNAr}_{5} \mathrm{NC}\right)_{2}\right] ; 4^{1}$

(e)

$\left[\mathrm{Ni}\left(\mathrm{CNAr}_{5}{ }^{(\text {th })} \mathrm{NC}\right)_{2}\right] \cdot 4^{1}$

Aside from square-planar $\mathrm{Ni}(\mathrm{II})$, tetrahedral $\mathrm{Ni}(\mathrm{o})$ complexes can exhibit long-lived excited states. Given the very large number of emissive $\mathrm{Cu}(\mathrm{I})$ complexes, it is somewhat surprising that only a handful of isoelectronic $\mathrm{Ni}(\mathrm{o})$ complexes are known to luminesce. ${ }^{62}$ The latest advances in this area were made with chelating isocyanide ligands, leading to the $\left[\mathrm{Ni}\left(\mathrm{CNAr}_{5} \mathrm{NC}\right)_{2}\right]$ and $\left[\mathrm{Ni}\left(\mathrm{CNAr}_{5}{ }^{(\text {th })} \mathrm{NC}\right)_{2}\right]$ complexes (Figure $5 \mathrm{~d} / \mathrm{e}) .{ }^{41}$ The respective ligands have peripheral aryl rings to restrict planarization in the
${ }^{3}$ MLCT excited state, ${ }^{63}$ a design principle that was inspired by the well-known $\left[\mathrm{Cu}(\mathrm{dpp})_{2}\right]^{+}$complex (Figure 6a)..$^{2}$ Nevertheless, these $\mathrm{Ni}(\mathrm{o})$ complexes are only luminescent well below room temperature (Table 3 ).
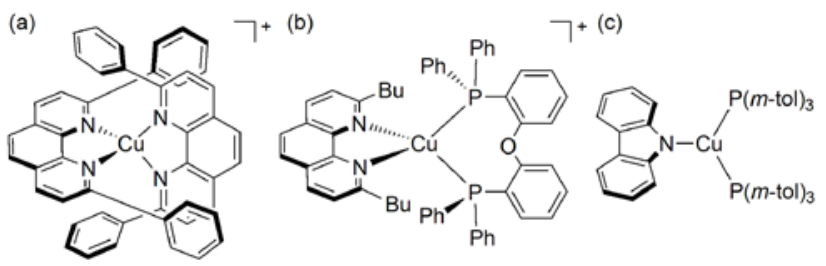

(d)

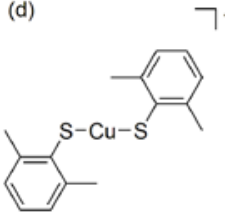

(e)

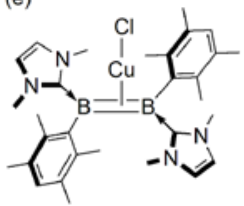

(f)

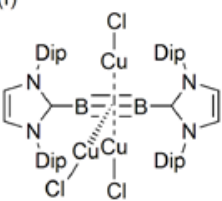

(g)
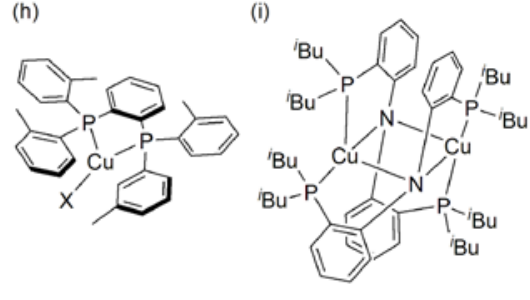

Figure 6. Molecular structures of $\mathrm{Cu}$ complexes: (a) $\left[\mathrm{Cu}(\mathrm{dpp})_{2}\right]^{+;} ; 4^{2} \quad$ (b) $[\mathrm{Cu}(\mathrm{dbp})(\mathrm{POP})]^{+; 43}$ (c) $[\mathrm{Cu}(\mathrm{cbz})(\mathrm{P}(m-$ tol $\left.\left.)_{3}\right)_{2}\right] ; 44$ (d) $\left[\mathrm{Cu}\left(\mathrm{SAr}^{\mathrm{Me} 2}\right)_{2}\right]^{-; 45}$ (e) $\left[\mathrm{Cu}\left(\mathrm{R}_{\mathrm{n}} \mathrm{B}=\mathrm{BR}_{\mathrm{n}}\right) \mathrm{Cl}\right] ; 46 \quad$ (f) $\left[\left(\mathrm{B}_{2} \mathrm{IDip}_{2}\right)(\mathrm{CuCl})_{3}\right] ; 47(\mathrm{~g})\left[(\mathrm{DAC})_{2} \mathrm{Cu}\right]^{+} ; 4^{8}(\mathrm{~h})[\mathrm{Cu}(\mathrm{dtpb}) \mathrm{X}], \mathrm{X}=$ $\mathrm{Cl}, \mathrm{Br}, \mathrm{I} ; 49$ (i) $[(\mathrm{PNP}) \mathrm{Cu}]_{2} .5^{\circ}$

\section{COPPER AND ZINC}

As noted in the introduction, the field of luminescent $\mathrm{Cu}(\mathrm{I})$ complexes is vast and only a selection of recent conceptually novel discoveries made in the past few years will be considered here. In particular $\alpha$-diimine $\mathrm{Cu}(\mathrm{I})$ complexes represent a very well investigated class of ${ }^{3}$ MLCT emitters. ${ }^{5}$ Whilst $\left[\mathrm{Cu}(\mathrm{dpp})_{2}\right]^{+}$(Figure 6a) can be considered as a prototype of this family of complexes, ${ }^{42}$ higher luminescence quantum yields can be obtained in combination with diphosphine ligands (e. g., in $[\mathrm{Cu}(\mathrm{dbp})(\mathrm{POP})]^{+}$, Figure $\left.6 \mathrm{~b}\right)$ and when sterically demanding substituents are present (Table 3 ), but this has long been known. ${ }^{42-43}$

Photoactive $\mathrm{Cu}(\mathrm{I})$ complexes are receiving increasing attention from the organic synthetic community. ${ }^{64}$ For photoredox catalysis, the lability of 3d-metal complexes can be attractive, because it permits relatively facile ligation of substrates to the metal center and the formation of substrate complexes that can become the photoactive species, ${ }^{65}$ similar to what is the case with some of the abovementioned Ni systems. This principle was exploited by the groups of Peters and $\mathrm{Fu}$, who found that the $\left[\mathrm{Cu}(\mathrm{cbz})\left(\mathrm{P}(m \text {-tol })_{3}\right)_{2}\right]$ complex (Figure 6c) reacts with iodo- and bromobenzene to give Ullman coupling products upon UV-irradiation at $-40{ }^{\circ} \mathrm{C} .44$ This formed the basis for a range of photoinduced Ullman couplings with various reaction partners where $\mathrm{CuI}$ or $\mathrm{CuCl}$ was typically the metal source, and substrate complexes with $\mathrm{Cu}(\mathrm{I})$ 
were presumed to be the photoactive species. In some cases, this could be corroborated by very detailed mechanistic studies, for example for the photoinduced C-S bond formation between aryl thiols and aryl halides. ${ }^{66}$ The use of a sterically somewhat congested arylthiolate permitted the isolation of the $\left[\mathrm{Cu}\left(\mathrm{SAr}^{\mathrm{Me} 2}\right)_{2}\right]^{-}$complex (Figure $6 \mathrm{~d}$ ), which exhibits a strongly reducing excited state with a lifetime of $7 \mu$ s (Table 3). ${ }^{45}$ Photoexcitation of this complex in the presence of aryl iodide substrate leads to a $\mathrm{Cu}(\mathrm{II})$ thiolate as a result of electron transfer to the aryl halide. Subsequent C-S bond formation between the formed aryl radical and the thiolate occurs very rapidly within the solvent cage according to radical clock experiments.

Aside from organic photoredox catalysis, $\mathrm{Cu}(\mathrm{I})$ complexes are receiving increasing attention in the contexts of photochemical hydrogen production and $\mathrm{CO}_{2}$ reduction. ${ }^{67}$ However, many of these studies rely on classical $\mathrm{Cu}(\mathrm{I})$ diimine or diphosphine complexes that will not be considered here.

A conceptually novel family of emissive $\mathrm{Cu}(\mathrm{I})$ complexes was recently reported by the groups of Braunschweig and Steffen. Side-on bound $\pi$-olefin complexes are wellknown, but analogous compounds with $\pi$-bound diborenes such as $\left[\mathrm{Cu}\left(\mathrm{R}_{\mathrm{n}} \mathrm{B}=\mathrm{BR}_{\mathrm{n}}\right) \mathrm{Cl}\right]$ (Figure 6e) are very rare. ${ }^{46}$ Whilst $\pi$-olefin complexes are usually nonemissive, $\left[\mathrm{Cu}\left(\mathrm{R}_{\mathrm{n}} \mathrm{B}=\mathrm{BR}_{\mathrm{n}}\right) \mathrm{Cl}\right]$ luminesces with a quantum yield of 0.18 in toluene (Table 3 ). Its short excited-state lifetime $(2.47 \mathrm{~ns})$ points to fluorescence, but the large Stokes shift $\left(6700 \mathrm{~cm}^{-1}\right)$ seems more compatible with phosphorescence. In-depth theoretical studies lead to the conclusion that this complex emits from a singlet state with pronounced intra-ligand charge transfer (ILCT) character. The coordination of $\mathrm{Cu}(\mathrm{I})$ to the diborene occurs predominantly through electrostatic interactions. In a follow-up study, the portfolio of emissive $\mathrm{Cu}(\mathrm{I}) \pi$ complexes was extended to diborynes. ${ }^{47}$ The trinuclear $\left[\left(\mathrm{B}_{2} \mathrm{IDip}_{2}\right)(\mathrm{CuCl})_{3}\right]$ complex (Figure $6 \mathrm{f}$ ) shows intense orange-red phosphorescence (Table 3). Compared to the $\pi$ diborene complex from above, metal d-orbital contributions to the HOMO and HOMO-1 in this $\pi$-diboryne complex are stronger, leading to significant MLCT character and more efficient intersystem crossing.

Cyclic alkyl(amino)carbene (CAAC) ligands recently provided access to linear $\mathrm{Cu}(\mathrm{I})$ complexes that strongly phosphoresce in the solid state ${ }^{68}$ contrasting with the very efficient non-radiative relaxation behavior commonly observed for analogous NHC complexes. ${ }^{69}$ These improved luminescence properties are intimately linked to the fact that CAACs exhibit superior $\sigma$-donating and $\pi$ accepting properties than NHCs, and this makes $\mathrm{Cu}(\mathrm{I})$ CAAC complexes useful for OLED applications. $7^{70}$ Two CAAC-CuCl complexes showed concentration-dependent luminescence with two peaks in methylcyclohexane, signaling dimer and excimer formation, possibly via $\mu$ bridging chlorides. ${ }^{11}$

The $\left[(\mathrm{DAC})_{2} \mathrm{Cu}\right]^{+}$complex by Thompson and Whittlesey (Figure 6g) exhibits an unusually high photoluminescence quantum yield of 0.65 in fluid $\mathrm{CH}_{2} \mathrm{Cl}_{2} \cdot{ }^{48}$ Its diamidocarbene ligands combine reduced $\sigma$-donor with enhanced $\pi$ acceptor properties compared to diamino ligands, and their steric bulk minimizes excited-state deactivation through librational motion of the aryl rings. The phosphorescence of $\left[(\mathrm{DAC})_{2} \mathrm{Cu}\right]^{+}$is barely quenched by oxygen due to the combined effects of steric protection of the metal center by the ligands and the high oxidation potential of the complex. Steric effects can also be exploited for obtaining three-coordinate $\mathrm{Cu}(\mathrm{I})$ complexes. ${ }^{49}$ Congesting diphosphine chelate ligands provided access to $\mathrm{Cu}(\mathrm{I})$ complexes (Figure 6h; $\mathrm{X}=\mathrm{Cl}, \mathrm{Br}, \mathrm{I}$ ) that phosphoresce with high quantum yields in dichloromethane (Table 3 ) and their use in OLEDs lead to very high external quantum efficiencies. These luminescence performances approach those of Peters' $\mathrm{Cu}_{2} \mathrm{~N}_{2}$ diamond core complex reported earlier (Figure 6i). ${ }^{\circ}$

Photoexcitation of dinuclear $\mathrm{Cu}(\mathrm{II})$ side-on peroxo complexes at $-80{ }^{\circ} \mathrm{C}$ was recently observed to lead to a stepwise one-photon two-electron oxidation chemistry of a metal-bound peroxide to $\mathrm{O}_{2} \cdot{ }^{72}$

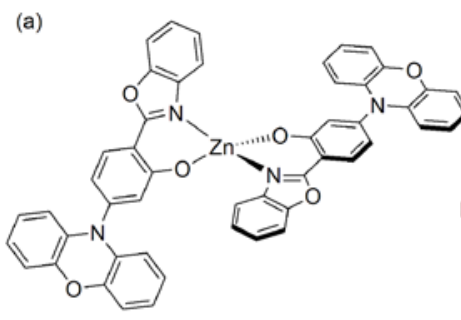

(c)

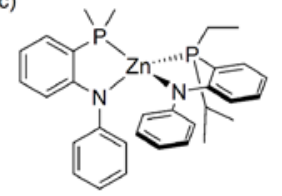

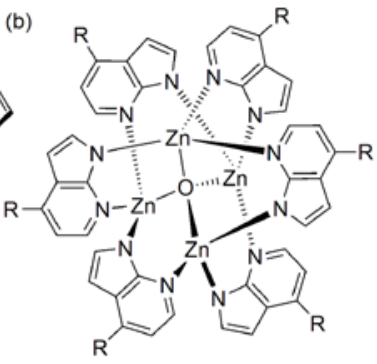

(d)

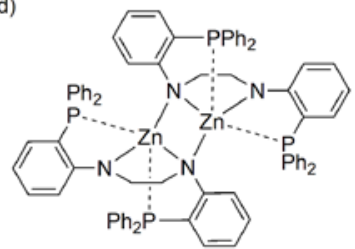

Figure 7. Molecular structures of Zn complexes: (a) [Zn(BOX$\left.\mathrm{OH})_{2}\right] ; 73 \quad$ (b) $\quad\left[\mathrm{Zn}_{4} \mathrm{O}(\text { pyrpy })_{6}\right] ; 51 \quad$ (c) $\left[(\mathrm{PN})_{2} \mathrm{Zn}\right] ; 52$

$[(\mathrm{PNNP}) \mathrm{Zn}]_{2} .53$

Zinc porphyrins remain a popular choice for photosensitization of electron transfer processes, and they are now also employed as photoredox catalysts, for example in polymerization reactions. ${ }^{74}$ Other $\mathrm{Zn}$ (II) complexes are receiving increasing attention as solid state emitters in OLEDs or as TADF (thermally activated delayed fluorescence) emitters (Figure $7 \mathrm{a}$ ), 73 but studies on $\mathrm{Zn}$ (II) complexes that emit in solution are less frequent. ${ }^{75} \mathrm{~A}$ series of tetranuclear $\mathrm{Zn}$ (II) complexes with pyrrolo-pyridine ligands (Figure $7 \mathrm{~b}$ ) exhibits bright blue-green fluorescence in $\mathrm{CH}_{2} \mathrm{Cl}_{2}\left(\left[\mathrm{Zn}_{4} \mathrm{O} \text { (pyrpy) }\right)_{6}\right]$, Table 3$) .{ }^{51} \mathrm{~A}$ highly stable $\mathrm{Zn}_{5}$ cluster has recently been found useful as a biocompatible fluorescent probe for detecting small tumors. ${ }^{76}$

Given the higher oxidation state of $\mathrm{Zn}(\mathrm{II})$ relative to isoelectronic $\mathrm{Cu}(\mathrm{I})$, MLCT states are usually at significantly higher energies, and this is a key reason why $\mathrm{Zn}(\mathrm{II})$ complexes have received less attention. The $\left[(\mathrm{PN})_{2} \mathrm{Zn}\right]$ complex (Figure 7c) luminesces weakly in benzene, but 
heteroleptic $\mathrm{Cu}(\mathrm{I})$ complexes with the same amidophosphine chelate and additional monodentate phosphine ligands are much stronger emitters..$^{22}$ The $[(\mathrm{PNNP}) \mathrm{Zn}]_{2}$ complex by Bestgen and Roesky (Figure $7 \mathrm{~d}$ ) luminesces with a quantum yield of 0.93 .53 The emission was attributed to ligand-centered luminescence.

\section{ZIRCONIUM}

As is evident from the prior sections, LMCT emitters are yet relatively rare among complexes with earthabundant metals. This makes the recent discoveries of luminescent $\mathrm{Zr}(\mathrm{IV})$ complexes all the more interesting. Bellemin-Lapponaz, Dargorne, and coworkers used a terdentate bis(aryloxide) NHC ligand to synthesize homoleptic air-stable $\mathrm{Ti}(\mathrm{IV}), \mathrm{Zr}(\mathrm{IV})$, and $\mathrm{Hf}(\mathrm{IV})$ complexes (Figure $8 \mathrm{a}) .{ }^{77}\left[\mathrm{Zr}\left((\mathrm{ArO})_{2} \mathrm{NHC}\right)_{2}\right]$ luminesces with a band maximum at $485 \mathrm{~nm}$ and a quantum yield of 0.08 in deaerated $\mathrm{CH}_{2} \mathrm{Cl}_{2}$ at $25{ }^{\circ} \mathrm{C}$. The corresponding $\mathrm{Hf}(\mathrm{IV})$ complex is also emissive. 77

The Milsmann group synthesized the $\left[\mathrm{Zr}\left({ }^{\mathrm{Me}} \mathrm{DPD}\right)_{2}\right]$ complex (Figure 8b) and found that it luminesces with a band maximum at $594 \mathrm{~nm}$ and a quantum yield of 0.08 in deoxygenated THF. ${ }^{8}$ The emission lifetime is $325 \mu$ s and strong quenching is observed in presence of $\mathrm{O}_{2}$, clearly indicating a phosphorescence process (Table 4)..$^{8}$ This long-lived triplet state can be quenched reductively by suitable sacrificial donors, and the resulting $\left[\mathrm{Zr}\left({ }^{\mathrm{Me}} \mathrm{DPD}\right)_{2}\right]^{-}$ species (also isolated as a crystalline solid) is a very strong reductant with $\mathrm{E}_{\mathrm{ox}}=-2.16 \mathrm{~V}$ vs. $\mathrm{Fc}^{+/ o}$. This has been exploited for photoredox catalysis. ${ }^{78-79}$ Combined computational and experimental studies lead to the conclusion that the emissive state has mixed 3LMCT and 3IL character. ${ }^{79}$ More recently, the Milsmann group synthesized and explored a related complex, $\left[\mathrm{Zr}\left({ }^{\mathrm{Me}} \mathrm{CNN}\right)_{2}\right]$, with $\mathrm{C}^{\wedge} \mathrm{N}^{\wedge} \mathrm{N}$ chelating ligands. ${ }^{80}$ In deaerated benzene solution that complex exhibits a luminescence lifetime of $412 \mu$ s and a quantum yield of 0.18 (Table 4).

Unfortunately, structurally analogous Ti(IV) complexes with the $\left((\mathrm{ArO})_{2} \mathrm{NHC}\right)$ and ${ }^{\mathrm{Me}} \mathrm{DPD}$ ligands were nonluminescent. ${ }^{77-78}$ With other ligands, luminescent Ti(IV) complexes are accessible, but so far essentially ligandbased fluorescence was observed. ${ }^{81} \mathrm{Zr}$ is a $2^{\text {nd }}$ row transition metal, but a quite abundant one (Table 1).

\section{MOLYBDENUM AND TUNGSTEN}

$\mathrm{Mo}(\mathrm{o})$ is isoelectronic with $\mathrm{Ru}(\mathrm{II})$ and consequently it seemed attractive to synthesize and explore a Mo analogue of $\left[\mathrm{Ru}(\mathrm{bpy})_{3}\right]^{2+}$ (bpy = 2,2'-bipyridine). Monodentate isocyanides had long been known to stabilize zero-valent group 6 metals, and recent studies on W(o) arylisocyanides provided the final inspiration. ${ }^{82}$ The $\left[\mathrm{Mo}\left(\mathrm{CN}^{\mathrm{Me}} \mathrm{Ar}_{3} \mathrm{NC}\right)_{3}\right]$ complex (Figure 8c) has three chelating diisocyanide ligands and exhibits optical spectroscopic properties that are strongly reminiscent of those of $\left[\mathrm{Ru}(\mathrm{bpy})_{3}\right]^{2+} .^{83} \mathrm{MLCT}$ absorptions in the blue-green spectral range are responsible for its orange color, and $3 \mathrm{MLCT}$ luminescence with lifetimes around 100-200 ns and quantum yields up to 0.045 were observed (Table 4). An important difference to $\left[\mathrm{Ru}(\mathrm{bpy})_{3}\right]^{2+}$ is of course the comparatively high reducing power of the ${ }^{3}$ MLCT-excited Mo(o) complex $\left(\mathrm{E}_{\mathrm{ox}}=-2.5 \mathrm{~V}\right.$ vs. $\left.\mathrm{Fc}^{+/ 0}\right),{ }^{32}$ and this can be exploited for photoredox catalysis, for example the light-driven rearrangement of an acyl cyclopropane into a 2,3dihydrofuran. ${ }^{83}$ (a) ${ }^{\mathrm{t}} \mathrm{Bu}$

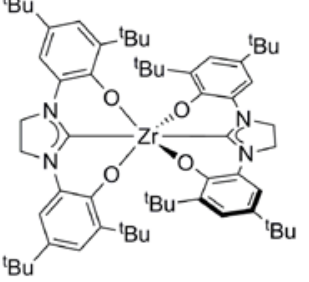

(c)

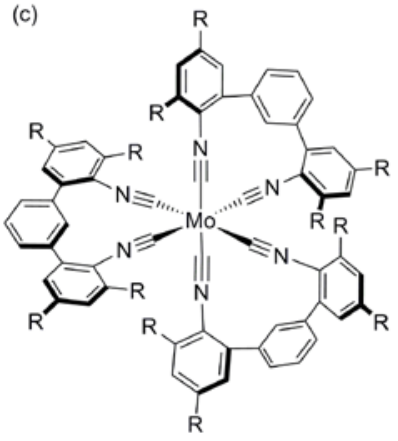

(e)

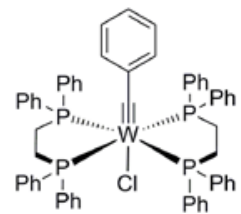

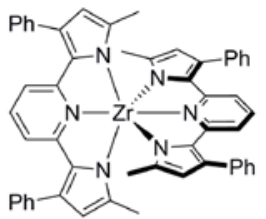

(d)
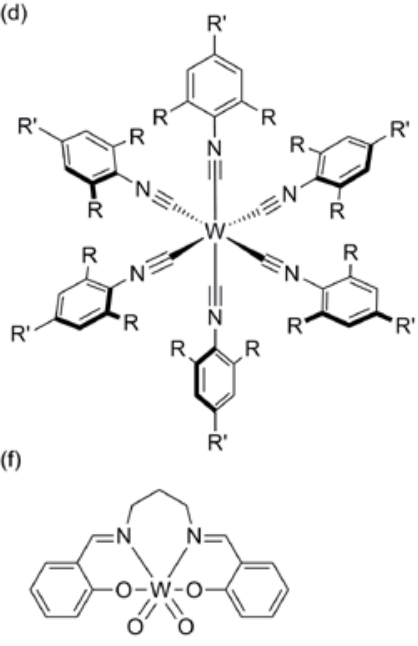

(g)

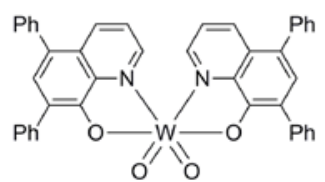

Figure 8. Molecular structures of $\mathrm{Zr}$, Mo and $\mathrm{W}$ complexes: $\begin{array}{llll}\text { (a) } \quad\left[\mathrm{Zr}\left((\mathrm{ArO})_{2} \mathrm{NHC}\right)_{2}\right] ; 77 & \text { (b) } \quad\left[\mathrm{Zr}\left({ }^{\mathrm{Me}} \mathrm{DPD}\right)_{2}\right] ; 7^{8-79} \quad \text { (c) }\end{array}$ $\left[\mathrm{Mo}\left(\mathrm{CN}^{\mathrm{Me}} \mathrm{Ar}_{3} \mathrm{NC}\right)_{3}\right] \quad(\mathrm{R}=\mathrm{Me}) ; 8_{3}$ (d) $\mathrm{R}={ }^{i} \mathrm{Pr}, \quad \mathrm{R}^{\prime}=\mathrm{H}:$ $\left[\mathrm{W}(\mathrm{CNdipp})_{6}\right] ; \mathrm{R}={ }^{i} \mathrm{Pr}, \mathrm{R}^{\prime}=\mathrm{C}_{6} \mathrm{H}_{5}:\left[\mathrm{W}(\mathrm{CNdippPh})_{6}\right] ;{ }^{82}$ (e) $\left[\mathrm{W}(\mathrm{CPh})(\mathrm{dppe})_{2} \mathrm{Cl}\right] ; 84 \quad$ (f) $\quad\left[\mathrm{WO}_{2}(\mathrm{PhONNOPh})\right] ; 8^{5} \quad$ (g) $\left[\mathrm{WO}_{2}\left(\mathrm{Ph}_{2} \text { quin }\right)_{2}\right] .{ }^{85}$

Before this development with chelating diisocyanide ligands and $\mathrm{Mo}(\mathrm{o})$ became possible in the Wenger group, a series of $\mathrm{W}(\mathrm{o})$ complexes with monodentate arylisocyanides had been reported by Gray, Winkler and coworkers. ${ }^{82}$ As a 5 d metal, tungsten is inherently more substitution-inert than the lighter group 6 elements, and there was no need for chelating ligands in order to obtain brightly emissive $\mathrm{W}(\mathrm{o})$ complexes. The ligands in this case were arylisocyanides comprised of single phenyl rings, biphenyls, or terphenyls equipped with bulky substituents in $\alpha$-position to the NC groups. ${ }^{32},{ }^{82}$ Whilst the [W(CNdipp $\left.)_{6}\right]$ parent compound (Figure $8 \mathrm{~d}$ ) has an excited-state lifetime of $122 \mathrm{~ns}$ and a luminescence quantum yield of 0.03 in deaerated toluene (Table 4), these properties are both improved by more 
Table 4. Valence electron configurations and photophysical properties of some $4 \mathrm{~d}$ and $5 \mathrm{~d}$ metal complexes.

\begin{tabular}{|c|c|c|c|c|c|}
\hline & config. & $\lambda_{\max }$ & $\tau$ & $\phi$ & exc. state \\
\hline$\left[\mathrm{Zr}\left((\mathrm{ArO})_{2} \mathrm{NHC}\right)_{2}\right]$ & $4 \mathrm{~d}^{\mathrm{o}}$ & $485 \mathrm{~nm}^{a}$ & & $0.08^{a}$ & \\
\hline$\left[\mathrm{Zr}\left(\mathrm{MeDPD}_{2}\right]\right.$ & $4 \mathrm{~d}^{\mathrm{o}}$ & $594 \mathrm{~nm}^{b}$ & $325 \mu \mathrm{s}^{b}$ & $0.08^{b}$ & 3LMCT/3IL \\
\hline$\left[\mathrm{Zr}\left({ }^{\mathrm{Me}} \mathrm{CNN}\right)_{2}\right]$ & $4 \mathrm{~d}^{\mathrm{o}}$ & $565 \mathrm{~nm}^{c}$ & $412 \mu \mathrm{s}^{c}$ & $0.18^{c}$ & 3LMCT/3IL \\
\hline$\left[\mathrm{Mo}\left(\mathrm{CN}^{\mathrm{Me}} \mathrm{Ar}_{3} \mathrm{NC}\right)_{3}\right]$ & $4 d^{6}$ & $596 \mathrm{~nm}^{d}$ & $225 \mathrm{~ns}^{d}$ & $0.045^{d}$ & 3MLCT \\
\hline [W(CNdipp) 6$]$ & $5 \mathrm{~d}^{6}$ & $575 \mathrm{~nm}^{e}$ & $122 \mathrm{~ns}^{e}$ & $0.03^{e}$ & 3MLCT/3IL/3LLCT \\
\hline$\left[\mathrm{W}(\mathrm{CNdippPh})_{6}\right]$ & $5 d^{6}$ & $617 \mathrm{~nm}^{e}$ & $1.73 \mu \mathrm{s}^{e}$ & $0.41^{e}$ & 3MLCT/3IL/3LLCT \\
\hline$\left[\mathrm{W}(\mathrm{CPh})(\mathrm{dppe})_{2} \mathrm{Cl}\right]$ & $5 d^{2}$ & $668 \mathrm{~nm}^{f}$ & $303 \mathrm{~ns}^{f}$ & $0.017^{f}$ & $3\left[d_{x y} \rightarrow \pi^{*}\right]$ \\
\hline$\left[\mathrm{WO}_{2}(\mathrm{PhONNOPh})\right]$ & $5^{\mathrm{d}^{\mathrm{o}}}$ & $600 \mathrm{~nm}^{g}$ & $96.9 \mu \mathrm{s} g$ & $0.028^{g}$ & $3 \mathrm{IL}$ \\
\hline$\left[\mathrm{WO}_{2}\left(\mathrm{Ph}_{2} \text { quin }\right)_{2}\right]$ & $5 \mathrm{~d}^{\mathrm{o}}$ & $515 / 614 \mathrm{~nm}^{g}$ & $42.0 \mu \mathrm{s}^{g}$ & $0.012^{g}$ & ${ }^{1} \mathrm{IL} / 3 \mathrm{IL}$ \\
\hline
\end{tabular}

$a$ in deaerated $\mathrm{CH}_{2} \mathrm{Cl}_{2} ; 77{ }^{b}$ in deaerated THF;78-79 $c$ in deaerated benzene; $80 \mathrm{~d}$ in deaerated $n$-hexane; $83 e$ in deaerated toluene;82 $f$ in deaerated toluene; ${ }^{84 a} g$ in deaerated $\mathrm{CH}_{2} \mathrm{Cl}_{2} \cdot{ }^{85}$

than an order of magnitude in $\left[\mathrm{W}(\mathrm{CNdippPh})_{6}\right]$ (Figure 8d, Table 4$)$. [W(CNdipp $\left.)_{6}\right]$ is an extremely strong photoreductant $\left(\mathrm{E}_{\mathrm{ox}}=-3.0 \mathrm{~V}\right.$ vs. $\left.\mathrm{Fc}^{+/ o}\right)$, able to reduce benzophenone to its ketyl radical anion. Combined transient infrared and computational studies demonstrated that the emissive states have mixed MLCT, LLCT, and intraligand character. ${ }^{86}$

Aside from these $\mathrm{W}(\mathrm{o})$ arylisocyanides, tungsten alkylidyne complexes represent an important class of photoactive complexes. This field has been reviewed, ${ }^{87}$ but there are important recent developments. Particularly promising are $\mathrm{d}^{2}$ tungsten alkylidynes of the type trans$\left[\mathrm{W}(\equiv \mathrm{CAr}) \mathrm{L}_{4} \mathrm{X}\right]$ where $\mathrm{L}$ is a neutral and $\mathrm{X}$ an anionic ligand (Figure 8e). The first oxidation potentials of these complexes are tunable over a range greater than 2 Volts through ligand variation. ${ }^{88}$ Many of these complexes are luminescent in solution at room temperature, exhibiting excited-state lifetimes between 10 and 500 ns combined with quantum yields around $10^{-4}$ to $10^{-2} .87$ The emissive states are so-called $3\left[\mathrm{~d}_{\mathrm{xy}} \rightarrow \pi^{*}\right]$ states, since the HOMO is usually a metal $\mathrm{d}_{\mathrm{xy}}$-orbital whilst a $\pi^{*}(\mathrm{~W} \equiv \mathrm{CAr})$ orbital is commonly the LUMO. The $\left[\mathrm{W}(\mathrm{CPh})(\mathrm{dppe})_{2} \mathrm{Cl}\right]$ complex (Figure 8e) was recently used for dihydrogen activation. ${ }^{84 \mathrm{~b}}$ Its one-electron oxidized $\left(\mathrm{d}^{1}\right)$ form reacts with $\mathrm{H}_{2}$ to give the $\mathrm{d}^{\circ}$ hydride complex $\left[\mathrm{W}(\mathrm{CPh})(\mathrm{H})(\mathrm{dppe})_{2} \mathrm{Cl}\right]^{+}$, which can be deprotonated to yield the emissive $\left[\mathrm{W}(\mathrm{CPh})(\mathrm{dppe})_{2} \mathrm{Cl}\right]\left(\mathrm{d}^{2}\right)$ chromophore. The latter has an excited-state lifetime of ca. $300 \mathrm{~ns}$ (Table 4) and is a strong reductant. ${ }^{8 \mathrm{a}}$ The observed reactivity of its oneelectron oxidized form with $\mathrm{H}_{2}$ opens the unique possibility to regenerate the oxidized photoredox catalyst with hydrogen rather than with commonly used sacrificial electron donors. ${ }^{84 \mathrm{~b}}$ This seems highly interesting for solar energy conversion.

A recently reported series of $\mathrm{W}(\mathrm{VI})$ dioxo complexes with conjugated Schiff base (Figure 8f) or quinolinolate ligands (Figure 8g) exhibits intra-ligand phosphorescence with quantum yields in the range of $0.001-0.028$ in $\mathrm{CH}_{2} \mathrm{Cl}_{2}$ (Table 4) ${ }^{85}$ For several of the quinolinolate complexes, for example $\left[\mathrm{WO}_{2}\left(\mathrm{Ph}_{2} \text { quin }\right)_{2}\right]$ (Figure 8g), dual fluorescence $(515 \mathrm{~nm})$ and phosphorescence $(614 \mathrm{~nm})$ occurs, and this can be exploited for ratiometric $\mathrm{O}_{2}$ sensing. Both types of complexes are useable as photoredox catalysts as exemplified by the light-induced cyanation of tertiary amines. The absence of deactivating $d-d$ states in $\mathrm{W}(\mathrm{VI})$ makes these compounds further attractive for OLED applications.

\section{CERIUM}

Cerium is more abundant in Earth's crust than copper (Table 1), and it is easily separated from other lanthanides by oxidation chemistry. It has long been known that $\mathrm{Ce}(\mathrm{III})$ has an emissive electronic excited state which is ${ }_{4} \mathrm{f}^{0} 5 \mathrm{~d}^{1}$ in nature, but this fact has only relatively recently been exploited systematically in molecular complexes in fluid solution. The group of $\mathrm{Su}$ encapsulated $\mathrm{Ce}(\mathrm{III})$ in several tripodal polybenzimidazole ligands. ${ }^{89}$ The resulting complexes have a $\mathrm{CeN}_{8}$ coordination sphere, and the $\left[\mathrm{Ce}(\text { triPrNTB })_{2}\right]^{3+}$ complex (Figure 9a) emits in ethanol at $298 \mathrm{~K}$. The emission is broad and consists of two overlapping bands due to electric-dipole allowed ${ }_{5} \mathrm{~d} \rightarrow{ }_{4} \mathrm{f}$ transitions to the ${ }^{2} \mathrm{~F}_{5 / 2}$ and ${ }^{2} \mathrm{~F}_{7 / 2}$ states derived from the $4 \mathrm{f}^{1}$ ground state electron configuration, as commonly observed for Ce(III). The emission quantum yield is high (0.55, Table 5), and this was attributed to shielding of the metal center by the tripodal encapsulating ligand.

The Schelter group along with the team of Anna has been very actively researching luminescent $\mathrm{Ce}(\mathrm{III})$ complexes and photosensitizers in recent years. Carbodiimides, $\mathrm{R}-\mathrm{N}=\mathrm{C}=\mathrm{N}-\mathrm{R}\left(\mathrm{R}={ }^{i} \mathrm{Pr}, \mathrm{Cy}\right)$, were used to form insertion products with $\mathrm{Ce}\left[\mathrm{N}\left(\mathrm{SiMe}_{3}\right)_{2}\right]_{3}$ to result in the bright green emitting $\mathrm{Ce}\left[\left(\mathrm{Me}_{3} \mathrm{Si}\right)_{2} \mathrm{NC}\left(\mathrm{NPr}_{2}\right)_{2}\right]\left[\mathrm{N}\left(\mathrm{SiMe}_{3}\right)_{2}\right]_{2}$ and $\mathrm{Ce}\left[\left(\mathrm{Me}_{3} \mathrm{Si}\right)_{2} \mathrm{NC}\left(\mathrm{N}^{\mathrm{Cy}}\right)_{2}\right]\left[\mathrm{N}\left(\mathrm{SiMe}_{3}\right)_{2}\right]_{2}$ complexes (Figure 9b)..$^{\circ}$ The $5 \mathrm{~d} \rightarrow 4 \mathrm{f}$ photoluminescence quantum yields of these two guanidinate complexes (o.46 and 0.54 , Table 5) are much higher than that of the parent amide complex $\mathrm{Ce}\left[\mathrm{N}\left(\mathrm{SiMe}_{3}\right)_{2}\right]_{3}(\mathrm{o.03})$. The ${ }_{5} \mathrm{~d} \rightarrow 4 \mathrm{f}$ emissions (involving the essentially non-bonding $5 \mathrm{~d}_{\mathrm{z} 2}$-orbital) are electricdipole allowed and hence the excited-state lifetimes are in 
Table 5. Valence electron configurations and photophysical properties of some Ce complexes exhibiting $5 \mathrm{~d} \rightarrow 4 \mathrm{f}$ emission.

\begin{tabular}{|l|l|l|l|}
\hline & $\lambda_{\max }$ & $\tau$ & $\phi$ \\
\hline$\left[\mathrm{Ce}(\mathrm{triPrNTB})_{2}\right]^{3^{+}}$ & $429 / 468 \mathrm{~nm}^{a}$ & $\sim 50 \mathrm{~ns}^{a}$ & $0.55^{a}$ \\
\hline $\mathrm{Ce}\left[\left(\mathrm{Me}{ }_{3} \mathrm{Si}\right)_{2} \mathrm{NC}\left(\mathrm{N}^{\mathrm{iPr}}\right)_{2}\right]\left[\mathrm{N}\left(\mathrm{SiMe}_{3}\right)_{2}\right]_{2}$ & $518 \mathrm{~nm}^{b}$ & $67 \mathrm{~ns}^{b}$ & $0.46^{b}$ \\
\hline $\mathrm{Ce}\left[\left(\mathrm{Me}_{3} \mathrm{Si}\right)_{2} \mathrm{NC}\left(\mathrm{N}^{\mathrm{Cy}}\right)_{2}\right]\left[\mathrm{N}\left(\mathrm{SiMe}_{3}\right)_{2}\right]_{2}$ & $523 \mathrm{~nm}^{b}$ & $61 \mathrm{~ns}^{b}$ & $0.54^{b}$ \\
\hline $\mathrm{Ce}\left[\left(\mathrm{Me}_{3} \mathrm{Si}\right)_{2} \mathrm{NC}\left(\mathrm{N}^{\mathrm{iPr}}\right)_{2}\right]_{3}$ & $459 \mathrm{~nm}^{c}$ & $83 \mathrm{~ns}^{c}$ & $0.81^{c}$ \\
\hline$[\mathrm{CeCl}]_{3} 3^{-}$ & $\sim 360 \mathrm{~nm}^{d}$ & $22.1 \mathrm{~ns}^{d}$ & $0.61^{d}$ \\
\hline
\end{tabular}

${ }^{a}$ in $\mathrm{EtOH} ;{ }^{89}{ }^{b}$ in toluene; $90 \mathrm{c}$ in toluene;91 ${ }^{d}$ in $\mathrm{CH}_{3} \mathrm{CN}$ with $0.1 \mathrm{M} \mathrm{Et}_{4} \mathrm{NCl} .9^{2}$

the nanosecond range (Table 5). Importantly, these excited states are strongly reducing $\left(\mathrm{E}_{\mathrm{ox}} \approx-\mathbf{2 . 3} \mathrm{V}\right.$ vs. $\left.\mathrm{Fc}^{+/ \mathrm{o}}\right)$, and this can be exploited for example for the light-driven reduction of benzyl chloride via an inner-sphere process, or for catalytic arylations of benzene leading to biphenyls. $9^{\circ}$ The inner-sphere reactivity of $\mathrm{Ce}\left[\left(\mathrm{Me}_{3} \mathrm{Si}\right)_{2} \mathrm{NC}\left(\mathrm{N}^{\mathrm{iPr}}\right)_{2}\right]\left[\mathrm{N}\left(\mathrm{SiMe}_{3}\right)_{2}\right]_{2}$ is contrasted by the outer-sphere redox chemistry displayed by the homoleptic tris(guanidinate) complex $\mathrm{Ce}\left[\left(\mathrm{Me}_{3} \mathrm{Si}\right)_{2} \mathrm{NC}\left(\mathrm{N}^{\mathrm{iPr}}\right)_{2}\right]_{3}(\mathrm{n}=3$ in Figure 9b). ${ }^{91}$ Steric encumbrance around the $\mathrm{Ce}(\mathrm{III})$ cation presumably prevents substrate binding in that case. Among the entire guanidinate-amide mixed-ligand series $(\mathrm{n}=\mathrm{o}-3$ in Figure $9 \mathrm{~b}$ ), the luminescence quantum yield increases with increasing number of guanidinate ligands, reaching a maximum of 0.81 for $\mathrm{Ce}\left[\left(\mathrm{Me}_{3} \mathrm{Si}\right)_{2} \mathrm{NC}\left(\mathrm{N}^{\mathrm{iPr}}\right)_{2}\right]_{3}$ (Table 5 ). The trend of increasing quantum yields is paralleled by a trend of decreasing Stokes shifts, suggesting that decreasing excited-state distortions contribute to the improved emission properties when more guanidinate ligands are present. Partly as a result of the large variations in Stokes shifts, the emission color is tunable, leading to band maxima between 459 and $553 \mathrm{~nm}$ in toluene. Similar trends were observed for a guanidinate-aryloxide mixed-ligand series of $\mathrm{Ce}(\mathrm{III})$ complexes (Figure 9c).91

(a)

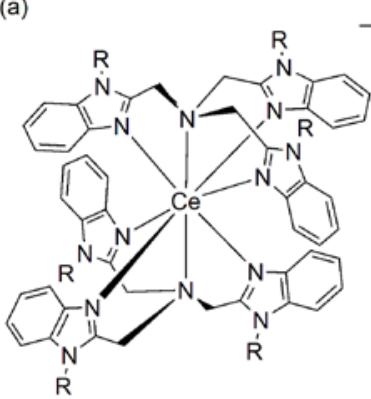

(b)

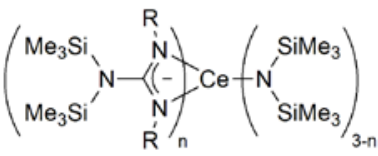

(c)

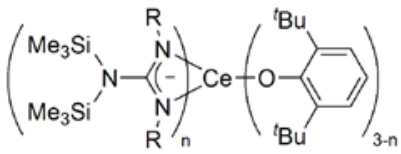

Figure 9. Molecular structures of $\mathrm{Ce}$ complexes: (a) $\left[\mathrm{Ce}(\text { triPrNTB })_{2}\right]^{3+}, \mathrm{R}={ }^{n} \mathrm{Pr} ; 89$ (b) guanidinate-amide complexes: $\mathrm{R}={ }^{i} \mathrm{Pr}, \mathrm{n}=1$ : $\mathrm{Ce}\left[\left(\mathrm{Me}_{3} \mathrm{Si}\right)_{2} \mathrm{NC}\left(\mathrm{N}^{\mathrm{iPr}}\right)_{2}\right]\left[\mathrm{N}\left(\mathrm{SiMe}_{3}\right)_{2}\right]_{2} ; 9^{\circ} \mathrm{R}=$ $\mathrm{Cy}, \mathrm{n}=1: \mathrm{Ce}\left[\left(\mathrm{Me}_{3} \mathrm{Si}\right)_{2} \mathrm{NC}(\mathrm{NCy})_{2}\right]\left[\mathrm{N}\left(\mathrm{SiMe}_{3}\right)_{2}\right]_{2} ; 9^{\circ} \mathrm{R}={ }^{i} \mathrm{Pr}, \mathrm{n}=3:$ $\mathrm{Ce}\left[\left(\mathrm{Me}_{3} \mathrm{Si}\right)_{2} \mathrm{NC}\left(\mathrm{NiPr}_{2}\right]_{3}, 9^{1}\right.$ (c) guanidinate-aryloxide complexes: $\mathrm{Ce}\left[\left(\mathrm{Me}_{3} \mathrm{Si}\right)_{2} \mathrm{NC}\left(\mathrm{N}^{\mathrm{iPr}}\right)_{2}\right]_{\mathrm{n}}(\mathrm{OAr})_{3-\mathrm{n}}, \mathrm{R}={ }^{i} \mathrm{Pr}, \mathrm{n}=\mathrm{o}-3 \cdot{ }^{11}$

Further studies demonstrated that the quantum yields of tris(guanidinate) complexes correlate with the steric demand of the group appended to the guanidinate ligand, and the $\mathrm{N}\left(\mathrm{SiMe}_{3}\right)_{2}$ group seems in fact optimal. ${ }^{93}$ As in many previously investigated lanthanide complexes, exclusion of solvent molecules from the coordination sphere is of key importance for obtaining high luminescence quantum yields.

The hexachlorocerate(III) anion is readily formed from $\mathrm{CeCl}_{3}$ in $\mathrm{CH}_{3} \mathrm{CN}$ in presence of excess $\mathrm{Et}_{4} \mathrm{NCl}$. $\left[\mathrm{CeCl}_{6}\right]^{3-}$ is air- and moisture-stable, and following UVA excitation it exhibits $5 \mathrm{~d} \rightarrow 4 \mathrm{f}$ emission at $\sim 360 \mathrm{~nm}$ with a lifetime of 22.1 ns and a quantum yield of 0.61 in $\mathrm{CH}_{3} \mathrm{CN}$ with $0.1 \mathrm{M}$ $\mathrm{Et}_{4} \mathrm{NCl} .^{92}$ This emissive excited state is extremely strongly reducing $\left(\mathrm{E}_{\mathrm{ox}}=-3.45 \mathrm{~V}\right.$ vs. $\left.\mathrm{Fc}^{+/ \mathrm{o}}\right)$, and this permits the stoichiometric dehalogenation of a variety of aryl chlorides under UVA irradiation. In the presence of excess toluene, the $\left[\mathrm{CeCl}_{6}\right]^{2-}$ oxidation product can be regenerated, and the dehalogenation of chlorobenzenes became viable with catalytic quantities of Ce using long UV irradiation times (3-6 days). More recently, the Schelter group used the $\left[\mathrm{CeCl}_{6}\right]^{3^{-}}$photoreductant for the light-driven Miyaura borylation of haloarenes. ${ }^{94}$

The group of Zuo found that Ce(IV) alkoxide complexes can be activated by light through LMCT excitation, leading to the generation of alkoxy radicals, and this is useful for photoredox catalysis. ${ }^{95}$ Very recently, the combination of LMCT excitation of Ce photocatalysts and HAT catalysis was exploited for the selective functionalization of methane, ethane, and higher alkanes. ${ }^{96}$

\section{SUMMARY AND OUTLOOK}

Precious metal complexes have long dominated inorganic photophysics and photochemistry, and they will likely continue to be important for many applications. Certain classes of photoactive base metal complexes have long been explored as well, but in recent years they are receiving much increased attention. Research in that area has become considerably broader, encompassing a diverse range of metal elements and different types of photoactive electronic excited states. Essentially all developments discussed herein were reported over the past 5 years, and there were others that could not be considered within the framework of this Perspective.

In some cases important new discoveries were made with metal ions that have long been on the radar of physical-inorganic chemists, for example with regard to $\mathrm{Cr}$ (III), $\mathrm{Fe}(\mathrm{II})$, $\mathrm{Co}(\mathrm{III})$, or $\mathrm{Cu}(\mathrm{I})$. Clever ligand design played a cen- 
tral role in many of these cases, sometimes inspired by lessons learned from research on precious metal complexes. In other cases, breakthroughs became possible as a result of the emerging interest in photoredox catalysis and the fact that a different community of researchers with a different mindset started to explore the possible photoactivity of a variety of metal complexes; $\mathrm{Ni}$ (II) is a good example of this type. In yet other cases, less common but long known coordination motifs were integrated into new (chelating) ligand types, giving access to metal complexes with highly promising photophysical and photochemical properties, for example in the cases of $\mathrm{Cr}(\mathrm{o})$, $\mathrm{Ni}(\mathrm{o}), \mathrm{Mo}(\mathrm{o})$, and $\mathrm{W}(\mathrm{o})$ isocyanides. Whilst MLCT emitters continue to play a central role, creative ligand design did also provide access to new LMCT luminophores, for example with $\mathrm{Fe}(\mathrm{III})$ or $\mathrm{Zr}(\mathrm{IV})$. Last but not least, among the f-elements molecular complexes of $\mathrm{Ce}$ (III) have been demonstrated to be applicable for a range of different photophysical and photochemical applications when embedded in proper coordination environments.

Aside from these synthetic advances brought about by creative minds and modern preparative methods, the field benefits from significant technological developments. UV-Vis transient absorption spectroscopy is becoming increasingly amenable in the form of reliable benchtop instruments, nowadays on timescales even below a few nanoseconds down to hundreds of femtoseconds. Transient infrared spectroscopy is getting more popular and will likely grow in importance. At the same time, timeresolved X-ray measurements and other synchrotronbased techniques become more broadly available in many different countries. These techniques will help to probe the molecular distortions associated with electronic excitations even in very short-lived excited states, and this will likely provide important insights in the future. Furthermore, input from computational chemistry is likely to become increasingly useful. 97

From a physical-inorganic viewpoint, it will be interesting to see what further developments are possible with $\mathrm{Fe}(\mathrm{II})$, in particular whether such complexes can become MLCT emitters in solution at room temperature. There might be other isoelectronic alternatives such as the example of $\mathrm{Cr}(\mathrm{o})$ discussed above. Likewise, several options for new spin-flip ligand-field emitters with $d^{2}$ or $d^{3}$ valence electron configurations seem within reach; $\mathrm{Mn}$ (IV) is only one possible example. ${ }^{15}, 35$ The recent spectacular discoveries of luminescent $\mathrm{Fe}(\mathrm{III})$ and $\mathrm{Zr}$ (IV) complexes are likely to stimulate further advances in the somewhat underexplored area of LMCT emitters.

From the organic photoredox point of view, the lability of 3d-metals seems attractive because it permits relatively facile ligation of substrates to the metal center, and the resulting complexes can become the key photoactive species. $\mathrm{Cu}(\mathrm{I})$ and $\mathrm{Ni}(\mathrm{II})$ complexes are likely to receive increasing attention for this reason, ${ }^{98}$ and such investigations will nicely complement photoredox studies made with organic sensitizers as alternatives to precious-metal based systems. 99
From the materials viewpoint, sensitizers for semiconductor solar cells and new luminophores made from earth-abundant metals remain very timely topics. In particular $\mathrm{Fe}(\mathrm{III}), \mathrm{Cr}(\mathrm{o}), \mathrm{Co}(\mathrm{III})$, and/or other $\mathrm{d}^{6}$ congeners now look more promising than ever for such applications. The combination of base metal photosensitizers with $\mathrm{CO}_{2}$ or proton reduction catalysts made from earth-abundant metals is likely to become another hot topic in the near future, stimulated by important recent progress on the side of the reduction catalysts. ${ }^{100}$

For more biologically oriented applications, for example the photochemical uncaging of bioactive molecules such as $\mathrm{CO}$ or $\mathrm{NO}$, 3d-metal complexes remain inherently interesting due the dissociative nature of the relevant $d-d$ excitations, ${ }^{2}$ yet for applications in photodynamic therapy, chemical robustness will likely be a key issue. ${ }^{101}$

Evidently the field of photoactive base metal complexes is flourishing, partly owed to the experience of wellestablished researchers and partly driven by a new generation of investigators with backgrounds in different areas. What is needed now are further creative, conceptually novel, and sometimes unconventional approaches like the ones seen over the past 5 years, leading to the discovery of fundamentally new types of photoactive metal complexes. When combined with modern (time-resolved) spectroscopic methods to unravel excited-state distortions and deactivation processes, much important progress can be anticipated. Nonradiative relaxation processes remain very difficult to probe and controlling them continues to be a bottleneck in the search for new photoactive metal complexes with electronic excited states that do not deactivate very rapidly.

\section{AUTHOR INFORMATION}

\section{Corresponding Author}

*oliver.wenger@unibas.ch.

\section{ACKNOWLEDGMENT}

The author thanks his coworkers for their contributions to the research performed by his group in this field; their names appear in the references. Generous support from the Swiss National Science Foundation, currently through grant number 200021_178760 and the NCCR Molecular Systems Engineering, is gratefully acknowledged.

\section{REFERENCES}

(1) Arias-Rotondo, D. M.; McCusker, J. K., Chem. Soc. Rev. 2016, 45, 5803-5820.

(2) Ford, P. C., Chem. Sci. 2016, 7, 2964-2986.

(3) Yuan, Y. J.; Yu, Z. T.; Chen, D. Q.; Zou, Z. G., Chem. Soc. Rev. 2017, 46, 603-631.

(4) Yam, V. W. W.; Wong, K. M. C., Chem. Commun. 2o11, 47, 11579-11592.

(5) (a) Czerwieniec, R.; Leitl, M. J.; Homeier, H. H. H.; Yersin, H., Coord. Chem. Rev. 2o16, 325, 2-28. (b) Mara, M. W.; Fransted, K. A.; Chen, L. X., Coord. Chem. Rev. 2015, 282, 2-18. (c) Housecroft, C. E.; Constable, E. C., Chem. Soc. Rev. 2015, 44 8386-8398. (d) Iwamura, M.; Takeuchi, S.; Tahara, T., Acc. Chem. Res. 2015, 48, 782-791. (e) Sandroni, M.; Pellegrin, Y.; Odobel, F., 
C. R. Chimie 2016, 19, 79-93. (f) Lazorski, M. S.; Castellano, F. N., Polyhedron 2014, 82, 57-70.

(6) Büldt, L. A.; Wenger, O. S., Chem. Sci. 2017, 8, 7359-7367.

(7) Holleman, A. F.; Wiberg, N., Lehrbuch der Anorganischen Chemie. 102th ed.; Walter de Gruyter: Berlin, 2007.

(8) Otto, S.; Grabolle, M.; Förster, C.; Kreitner, C.; ReschGenger, U.; Heinze, K., Angew. Chem. Int. Ed. 2015, 54, 1157211576.

(9) Wang, C.; Otto, S.; Dorn, M.; Kreidt, E.; Lebon, J.; Srsan, L.; Di Martino-Fumo, P.; Gerhards, M.; Resch-Genger, U.; Seitz, M.; Heinze, K., Angew. Chem. Int. Ed. 2018, 57, 1112-1116.

(10) Otto, S.; Dorn, M.; Förster, C.; Bauer, M.; Seitz, M.; Heinze, K., Coord. Chem. Rev. 2018, 359, 102-111.

(11) Otto, S.; Förster, C.; Wang, C.; Resch-Genger, U.; Heinze, K., Chem. Eur. J. 2018, doi: 10.1002/chem.201802797.

(12) Otto, S.; Harris, J. P.; Heinze, K.; Reber, C., Angew. Chem. Int. Ed. 2018, doi: 10.1002/anie.201806755.

(13) Stevenson, S. M.; Shores, M. P.; Ferreira, E. M., Angew. Chem. Int. Ed. 2015, 54, 6506-6510.

(14) Büldt, L. A.; Guo, X. W.; Vogel, R.; Prescimone, A.; Wenger, O. S., J. Am. Chem. Soc. 2017, 139, 985-992.

(15) Sharma, N.; Jung, J.; Ohkubo, K.; Lee, Y.-M.; El-Khouly, M. E.; Nam, W.; Fukuzumi, S., J. Am. Chem. Soc. 2018, 140, 84058409 .

(16) Otto, S.; Scholz, N.; Behnke, T.; Resch-Genger, U.; Heinze, K., Chem. Eur. J. 2017, 23, 12131-12135.

(17) Otto, S.; Nauth, A. M.; Emilov, E.; Scholz, N.; Friedrich, A.; Resch-Genger, U.; Lochbrunner, S.; Opatz, T.; Heinze, K., ChemPhotoChem 2017, 1, 344-349.

(18) McDaniel, A. M.; Tseng, H. W.; Damrauer, N. H.; Shores, M. P., Inorg. Chem. 2010, 49, 7981-7991.

(19) Liu, Y. Z.; Harlang, T.; Canton, S. E.; Chabera, P.; SuarezAlcantara, K.; Fleckhaus, A.; Vithanage, D. A.; Goransson, E.; Corani, A.; Lomoth, R.; Sundström, V.; Wärnmark, K., Chem. Commun. 2013, 49, 6412-6414.

(20) (a) Duchanois, T.; Etienne, T.; Cebrian, C.; Liu, L.; Monari, A.; Beley, M.; Assfeld, X.; Haacke, S.; Gros, P. C., Eur. J. Inorg. Chem. 2015, 2469-2477. (b) Liu, L.; Duchanois, T.; Etienne, T.; Monari, A.; Beley, M.; Assfeld, X.; Haacke, S.; Gros, P. C., Phys. Chem. Chem. Phys. 2016, 18, 12550-12556.

(21) Harlang, T. C. B.; Liu, Y. Z.; Gordivska, O.; Fredin, L. A.; Ponseca, C. S.; Huang, P.; Chabera, P.; Kjaer, K. S.; Mateos, H.; Uhlig, J.; Lomoth, R.; Wallenberg, R.; Styring, S.; Persson, P.; Sundström, V.; Wärnmark, K., Nat. Chem. 2015, 7, 883-889.

(22) Zimmer, P.; Burkhardt, L.; Friedrich, A.; Steube, J.; Neuba, A.; Schepper, R.; Müller, P.; Florke, U.; Huber, M.; Lochbrunner, S.; Bauer, M., Inorg. Chem. 2018, 57, 360-373.

(23) Leshchev, D.; Harlang, T. C. B.; Fredin, L. A.; Khakhulin, D.; Liu, Y. Z.; Biasin, E.; Laursen, M. G.; Newby, G. E.; Haldrup, K.; Nielsen, M. M.; Wärnmark, K.; Sundström, V.; Persson, P.; Kjaer, K. S.; Wulff, M., Chem. Sci. 2018, 9, 405-414.

(24) Jamula, L. L.; Brown, A. M.; Guo, D.; McCusker, J. K., Inorg. Chem. 2014, 53, 15-17.

(25) Shepard, S. G.; Fatur, S. M.; Rappe, A. K.; Damrauer, N. H., J. Am. Chem. Soc. 2016, 138, 2949-2952.

(26) Chabera, P.; Kjaer, K. S.; Prakash, O.; Honarfar, A.; Liu, Y. Z.; Fredin, L. A.; Harlang, T. C. B.; Lidin, S.; Uhlig, J.; Sundström, V.; Lomoth, R.; Persson, P.; Wärnmark, K., J. Phys. Chem. Lett. 2018, 9, 459-463.

(27) Chabera, P.; Liu, Y.; Prakash, O.; Thyrhaug, E.; El Nahhas, A.; Honarfar, A.; Essén, S.; Fredin, L. A.; Harlang, T. C. B.; Kjaer, K. S.; Handrup, K.; Ericsson, F.; Tatsuno, Y.; Morgan, K.; Schnadt, J.; Häggström, L.; Ericsson, T.; Sobkowiak, A.; Lidin, S.; Huang, P.; Styring, S.; Uhlig, J.; Bendix, J.; Lomoth, R.; Sundström, V.; Persson, P.; Wärnmark, K., Nature 2017, 543, 695699.
(28) Pal, A. K.; Li, C. F.; Hanan, G. S.; Zysman-Colman, E., Angew. Chem. Int. Ed. 2018, 57, 8027-8031.

(29) Stevenson, S. M.; Higgins, R. F.; Shores, M. P.; Ferreira, E. M., Chem. Sci. 2017, 8, 654-66o.

(30) Higgins, R. F.; Fatur, S. M.; Shepard, S. G.; Stevenson, S. M.; Boston, D. J.; Ferreira, E. M.; Damrauer, N. H.; Rappe, A. K.; Shores, M. P., J. Am. Chem. Soc. 2o16, 138, 5451-5464.

(31) Sarabia, F. J.; Li, Q.; Ferreira, E. M., Angew. Chem. Int. Ed. 2018, doi: 10.1002/anie.201805732.

(32) Büldt, L. A.; Wenger, O. S., Angew. Chem. Int. Ed. 2017, $56,5676-5682$.

(33) Berezin, A. S.; Vinogradova, K. A.; Nadolinny, V. A.; Sukhikh, T. S.; Krivopalov, V. P.; Nikolaenkova, E. B.; Bushuev, M. B., Dalton Trans. 2018, 47, 1657-1665.

(34) Suffren, Y.; O'Toole, N.; Hauser, A.; Jeanneau, E.; Brioude, A.; Desroches, C., Dalton Trans. 2015, 44, 7991-80oo.

(35) Baslon, V.; Harris, J. P.; Reber, C.; Colmer, H. E.; Jackson, T. A.; Forshaw, A. P.; Smith, J. M.; Kinney, R. A.; Telser, J., Can. J. Chem. 2017, 95, 547-552.

(36) Liu, Y. Z.; Persson, P.; Sundström, V.; Wärnmark, K., Acc. Chem. Res. 2016, 49, 1477-1485.

(37) Huynh, H. V., Chem. Rev. 2018, doi: 10.1021/acs.chemrev.8booo67.

(38) (a) Fredin, L. A.; Papai, M.; Rozsalyi, E.; Vanko, G.; Wärnmark, K.; Sundström, V.; Persson, P., J. Phys. Chem. Lett. 2014, 5, 2066-2071. (b) Liu, Y. Z.; Kjaer, K. S.; Fredin, L. A.; Chabera, P.; Harlang, T.; Canton, S. E.; Lidin, S.; Zhang, J. X.; Lomoth, R.; Bergquist, K. E.; Persson, P.; Wärnmark, K.; Sundström, V., Chem.-Eur. J. 2015, 21, 3628-3639.

(39) Francés-Monerris, A.; Magra, K.; Darari, M.; Cebrián, C.; Beley, M.; Domenichini, E.; Haacke, S.; Pastore, M.; Assfeld, X.; Gros, P. C.; Monari, A., Inorg. Chem. 2018, doi: 10.1021/acs.inorgchem.8bo1695.

(40) Hauser, A.; Reber, C., Struct. Bonding 2016, 172, 291-312.

(41) Büldt, L. A.; Larsen, C. B.; Wenger, O. S., Chem. Eur. J. 2017, 23, 8577-8580.

(42) Armaroli, N., Chem. Soc. Rev. 2001, 30, 113-124.

(43) Cuttell, D. G.; Kuang, S. M.; Fanwick, P. E.; McMillin, D. R.; Walton, R. A., J. Am. Chem. Soc. 2002, 124, 6-7.

(44) Creutz, S. E.; Lotito, K. J.; Fu, G. C.; Peters, J. C., Science 2012, 338, 647-651.

(45) Johnson, M. W.; Hannoun, K. I.; Tan, Y. C.; Fu, G. C.; Peters, J. C., Chem. Sci. 2016, 7, 4091-410o.

(46) Bissinger, P.; Steffen, A.; Vargas, A.; Dewhurst, R. D.; Damme, A.; Braunschweig, H., Angew. Chem. Int. Ed. 2015, 54, 4362-4366.

(47) Braunschweig, H.; Dellermann, T.; Dewhurst, R. D.; Hupp, B.; Kramer, T.; Mattock, J. D.; Mies, J.; Phukan, A. K.; Steffen, A.; Vargas, A., J. Am. Chem. Soc. 2017, 139, 4887-4893.

(48) Shi, S.; Collins, L. R.; Mahon, M. F.; Djurovich, P. I.; Thompson, M. E.; Whittlesey, M. K., Dalton Trans. 2017, 46, 745752.

(49) Hashimoto, M.; Igawa, S.; Yashima, M.; Kawata, I.; Hoshino, M.; Osawa, M., J. Am. Chem. Soc. 2011, 133, 10348-10351.

(50) Harkins, S. B.; Peters, J. C., J. Am. Chem. Soc. 2005, 127, 2030-2031.

(51) Cheng, G.; So, G. K. M.; To, W. P.; Chen, Y.; Kwok, C. C.; Ma, C. S.; Guan, X. G.; Chang, X.; Kwok, W. M.; Che, C. M., Chem. Sci. 2015, 6, 4623-4635.

(52) Miller, A. J. M.; Dempsey, J. L.; Peters, J. C., Inorg. Chem. 2007, 46, 7244-7246.

(53) Bestgen, S.; Schoo, C.; Neumeier, B. L.; Feuerstein, T. J.; Zovko, C.; Köppe, R.; Feldmann, C.; Roesky, H., Angew. Chem. Int. Ed. 2018, doi: 10.1002/anie.201806943.

(54) Fatur, S. M.; Shepard, S. G.; Higgins, R. F.; Shores, M. P.; Damrauer, N. H., J. Am. Chem. Soc. 2017, 139, 4493-4505. 
(55) Harris, C. F.; Kuehner, C. S.; Bacsa, J.; Soper, J. D., Angew. Chem. Int. Ed. 2018, 57, 1311-1315.

(56) Saracini, C.; Malik, D. D.; Sankaralingam, M.; Lee, Y.-M.; El-Khouly, M. E.; Nam, W.; Fukuzumi, S., Inorg. Chem. 2018, 57, 10945-10952.

(57) Brigham, E. C.; Achey, D.; Meyer, G. J., Polyhedron 2014 $82,181-190$

(58) Heitz, D. R.; Tellis, J. C.; Molander, G. A., J. Am. Chem. Soc. 2016, 138, 12715-12718.

(59) Welin, E. R.; Le, C.; Arias-Rotondo, D. M.; McCusker, J. K.; MacMillan, D. W. C., Science 2017, 355, 380-384.

(6o) Shields, B. J.; Kudisch, B.; Scholes, G. D.; Doyle, A. G., J. Am. Chem. Soc. 2018, 140, 3035-3039.

(61) Grübel, M.; Bosque, I.; Altmann, P. J.; Bach, T.; Hess, C. R., Chem. Sci. 2018, 9, 3313-3317.

(62) Malzkuhn, S.; Wenger, O. S., Coord. Chem. Rev. 2018, 359, 52-56.

(63) Büldt, L. A.; Wenger, O. S., Dalton Trans. 2017, 46, 1517515177 .

(64) (a) Reiser, O., Acc. Chem. Res. 2016, 49, 1990-1996. (b) Minozzi, C.; Caron, A.; Grenier-Petel, J. C.; Santandrea, J.; Collins, S. K., Angew. Chem. Int. Ed. 2018, 57, 5477-5481.

(65) Larsen, C. B.; Wenger, O. S., Chem.-Eur. J. 2018, 24, 20392058

(66) Uyeda, C.; Tan, Y. C.; Fu, G. C.; Peters, J. C., J. Am. Chem. Soc. 2013, 135, 9548-9552.

(67) (a) Rosas-Hernandez, A.; Steinlechner, C.; Junge, H.; Beller, M., Green Chem. 2017, 19, 2356-236o. (b) Zhang, Y.; Schulz, M.; Wächtler, M.; Karnahl, M.; Dietzek, B., Coord. Chem. Rev. 2018, 356, 127-146. (c) Khnayzer, R. S.; McCusker, C. E.; Olaiya, B. S.; Castellano, F. N., J. Am. Chem. Soc. 2013, 135, 1406814070. (d) Heberle, M.; Tschierlei, S.; Rockstroh, N.; Ringenberg, M.; Frey, W.; Junge, H.; Beller, M.; Lochbrunner, S.; Karnahl, M., Chem.-Eur. J. 2017, 23, 312-319.

(68) (a) Gernert, M.; Müller, U.; Haehnel, M.; Pflaum, J.; Steffen, A., Chem. Eur. J. 2017, 23, 2206-2216. (b) Romanov, A. S.; Becker, C. R.; James, C. E.; Di, D. W.; Credgington, D.; Linnolahti, M.; Bochmann, M., Chem.-Eur. J. 2017, 23, 4625-4637.

(69) (a) Visbal, R.; Gimeno, M. C., Chem. Soc. Rev. 2014, 43 3551-3574. (b) Krylova, V. A.; Djurovich, P. I.; Whited, M. T.; Thompson, M. E., Chem. Commun. 2010, 46, 6696-6698. (c) Krylova, V. A.; Djurovich, P. I.; Conley, B. L.; Haiges, R.; Whited, M. T.; Williams, T. J.; Thompson, M. E., Chem. Commun. 2014, 50, 7176-7179. (d) Marion, R.; Sguerra, F.; Di Meo, F.; Sauvageot, E.; Lohier, J. F.; Daniellou, R.; Renaud, J. L.; Linares, M.; Hamel, M.; Gaillard, S., Inorg. Chem. 2014, 53, 9181-9191.

(70) Di, D. W.; Romanov, A. S.; Yang, L.; Richter, J. M.; Rivett, J. P. H.; Jones, S.; Thomas, T. H.; Jalebi, M. A.; Friend, R. H.; Linnolahti, M.; Bochmann, M.; Credgington, D., Science 2017, 356, 159-163.

(71) Hamze, R.; Jazzar, R.; Soleilhavoup, M.; Djurovich, P. I.; Bertrand, G.; Thompson, M. E., Chem. Commun. 2017, 53, 90089011.

(72) Saracini, C.; Ohkubo, K.; Suenobu, T.; Meyer, G. J.; Karlin, K. D.; Fukuzumi, S., J. Am. Chem. Soc. 2015, 137, 15865-15874.

(73) Sakai, Y.; Sagara, Y.; Nomura, H.; Nakamura, N.; Suzuki, Y.; Miyazaki, H.; Adachi, C., Chem. Commun. 2015, 51, 3181-3184.

(74) (a) Shanmugam, S.; Xu, J. T.; Boyer, C., J. Am. Chem. Soc. 2015, 137, 9174-9185. (b) Jasinska, K. R.; Shan, W. Q.; Zawada, K.; Kadish, K. M.; Gryko, D., J. Am. Chem. Soc. 2016, 138, 15451-15458.

(75) Bizzarri, C.; Spuling, E.; Knoll, D. M.; Volz, D.; Bräse, S., Coord. Chem. Rev. 2018, doi: 10.1016/j.ccr.2017.1009.1011.

(76) Zeng, M. H.; Yin, Z.; Liu, Z. H.; Xu, H. B.; Feng, Y. C.; Hu, Y. Q.; Chang, L. X.; Zhang, Y. X.; Huang, J.; Kurmoo, M., Angew. Chem. Int. Ed. 2016, 55, 11407-11411.
(77) Romain, C.; Choua, S.; Collin, J. P.; Heinrich, M.; Bailly, C.; Karmazin-Brelot, L.; Bellemin-Laponnaz, S.; Dagorne, S., Inorg. Chem. 2014, 53, 7371-7376.

(78) Zhang, Y.; Petersen, J. L.; Milsmann, C., J. Am. Chem. Soc. 2016, 138, 13115-13118.

(79) Zhang, Y.; Lee, T. S.; Petersen, J. L.; Milsmann, C., J. Am. Chem. Soc. 2018, 140, 5934-5947.

(8o) Zhang, Y.; Petersen, J. L.; Milsmann, C., Organometallics 2018, doi: 10.1021/acs.organomet.8boo388.

(81) Khalil, G.; Orvain, C.; Fang, L.; Barloy, L.; Chaumont, A.; Gaiddon, C.; Henry, M.; Kyritsakas, N.; Mobian, P., Dalton Trans. 2016, 45, 19072-19085.

(82) (a) Sattler, W.; Ener, M. E.; Blakemore, J. D.; Rachford, A. A.; LaBeaume, P. J.; Thackeray, J. W.; Cameron, J. F.; Winkler, J. R.; Gray, H. B., J. Am. Chem. Soc. 2013, 135, 10614-10617. (b) Sattler, W.; Henling, L. M.; Winkler, J. R.; Gray, H. B., J. Am. Chem. Soc. 2015, 137, 1198-1205.

(83) Büldt, L. A.; Guo, X. W.; Prescimone, A.; Wenger, O. S., Angew. Chem. Int. Ed. 2016, 55, 11247-11250.

(84) (a) Lovaasen, B. M.; Lockard, J. V.; Cohen, B. W.; Yang, S. J.; Zhang, X. Y.; Simpson, C. K.; Chen, L. X.; Hopkins, M. D., Inorg. Chem. 2012, 51, 5660-5670. (b) Morales-Verdejo, C. A.; Newsom, M. I.; Cohen, B. W.; Vibbert, H. B.; Hopkins, M. D., Chem. Commun. 2013, 49, 10566-10568.

(85) Yeung, K. T.; To, W. P.; Sun, C. Y.; Cheng, G.; Ma, C. S.; Tong, G. S. M.; Yang, C.; Che, C. M., Angew. Chem. Int. Ed. 2017 , 56, 133-137.

(86) Kvapilova, H.; Sattler, W.; Sattler, A.; Sazanovich, I. V.; Clark, I. P.; Towrie, M.; Gray, H. B.; Zalis, S.; Vlcek, A., Inorg. Chem. 2015, 54, 8518-8528.

(87) Da Re, R. E.; Hopkins, M. D., Coord. Chem. Rev. 2005, 249, 1396-1409.

(88) (a) Haines, D. E.; O'Hanlon, D. C.; Manna, J.; Jones, M. K.; Shaner, S. E.; Sun, J. B.; Hopkins, M. D., Inorg. Chem. 2013, 52, 9650-9658. (b) Rudshteyn, B.; Vibbert, H. B.; May, R.; Wasserman, E.; Warnke, I.; Hopkins, M. D.; Batista, V. S., ACS Catal. 2017, 7, 6134-6143.

(89) Zheng, X. L.; Liu, Y.; Pan, M.; Lü, X. Q.; Zhang, J. Y.; Zhao, C. Y.; Tong, Y. X.; Su, C. Y., Angew. Chem. Int. Ed. 2007, 46, 73997403.

(90) Yin, H. L.; Carroll, P. J.; Anna, J. M.; Schelter, E. J., J. Am. Chem. Soc. 2015, 137, 9234-9237.

(91) Yin, H. L.; Carroll, P. J.; Manor, B. C.; Anna, J. M.; Schelter, E. J., J. Am. Chem. Soc. 2016, 138, 5984-5993.

(92) Yin, H. L.; Jin, Y.; Hertzog, J. E.; Mullane, K. C.; Carroll, P. J.; Manor, B. C.; Anna, J. M.; Schelter, E. J., J. Am. Chem. Soc. 2016, 138, 16266-16273.

(93) Qiao, Y. S.; Sergentu, D. C.; Yin, H. L.; Zabula, A. V.; Cheisson, T.; McSkimming, A.; Manor, B. C.; Carroll, P. J.; Anna, J. M.; Autschbach, J.; Schelter, E. J., J. Am. Chem. Soc. 2018, 140, 4588-4595.

(94) Qiao, Y.; Yang, Q.; Schelter, E. J., Angew. Chem. Int. Ed. 2018, 57, 10999-11003.

(95) (a) Guo, J. J.; Hu, A. H.; Chen, Y. L.; Sun, J. F.; Tang, H. M.; Zuo, Z. W., Angew. Chem. Int. Ed. 2016, 55, 15319-15322. (b) Hu, A. H.; Guo, J. J.; Pan, H.; Tang, H. M.; Gao, Z. B.; Zuo, Z. W., J. Am. Chem. Soc. 2018, 140, 1612-1616.

(96) Hu, A.; Guo, J. J.; Zuo, Z., Science 2018, doi: 10.1126/science.aat9750.

(97) Ashley, D. C.; Jakubikova, E., Coord. Chem. Rev. 2017, 337, 97-111.

(98) Lim, C. H.; Kudisch, M.; Liu, B.; Miyake, G. M., J. Am. Chem. Soc. 2018, 140, 7667-7673.

(99) Romero, N. A.; Nicewicz, D. A., Chem. Rev. 2016, 116, 10075-10166.

(100) Rao, H.; Schmidt, L. C.; Bonin, J.; Robert, M., Nature 2017, 548, 74-77. 
(101) (a) Heinemann, F.; Karges, J.; Gasser, G., Acc. Chem. Res. 2017, 50, 2727-2736. (b) White, J. K.; Schmehl, R. H.; Turro, C., Inorg. Chim. Acta 2017, 454, 7-20. 
Table of Contents artwork

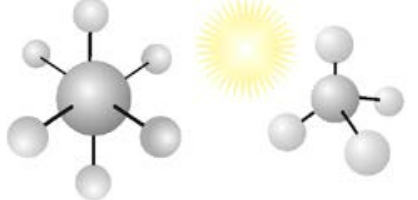

$\mathrm{Cr} \mathrm{MnFe} \mathrm{Co} \mathrm{Ni} \mathrm{Cu} \mathrm{Zn} \mathrm{Zr}$ Mo W $\mathrm{Ce}$ 